\title{
Comment
}

\section{A Model Negative Income Tax Statute*}

After four years, the War on Poverty has produced little more than a series of inconclusive skirmishes, despite the clear need for a farreaching, comprehensive attack on the problems of the poor. ${ }^{1}$ Meager efforts to provide the underprivileged with in-kind assistance or with special education and job training have had but little effect," while the traditional means of public assistance ${ }^{3}$ have failed to raise out of poverty even the ferw families they reach. ${ }^{*}$ In the face of such difficulties, public support for such programs has faltered; at the same

* The Law Journal wishes to thank Professors Edward Sparer and Boris I. Bituker of the Yale Economics Department for their helpful suggestions and consistent cooperation. The model statute was originally intended to follow closely the proposals found in Tobin, Pechman 8. Mieszkowski, Is a Negative Income Tax Practical? 77 YALE L.J. 1 (1967), but in the course of drafting, many of its provisions have gone bejond or diverged substantially from those earlier proposals. Special assistance was given by Kenneth C. Bass III of the Law Joumal.

1. For the recent emergence of poverty as a public issuc, sec S. Levrran, TuE Desig: of FEDERAL ANTIPOVERTY STRATECX (1967). Several public and private study groups have advocated a thorough overhaul of our antipoverty efforts. U.S. ADrisons Councll ox

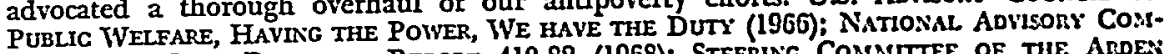

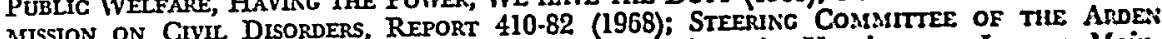
HOUSE CONFERENCE ON PUBLIC WELFARE, REPORT (1968), in Hearings on Income Maintenance Programs Before the Subcomm. on Fiscal Policy of the Joint Economic Commiltee, 90th Cong., 2d Sess. (1968) [hereinafter cited as Income Maintenance Hearings]. See generally Income Maintenance Hearings.

2. See the excellent summary of present deficiencies and future needs in the areas of housing, job training, and education in NATIONAL ADVISORY CoMsission ON CIVIL DISORDERs, RFPORT 410-56, 467-82 (1968). On food programs, see generally Citizes's BoAss of INQUIRY INTO HUNGER AND MALNUTRITION IN THE UNITED STATES, HuNGER, U.S.A. (1968).

3. Public assistance is the generic name for several programs under the Social Security Act which give financial aid, part federal and part local, to certain categories of persons upon a showing of need. The programs include Aid to the Blind, Social Security Act of 1935, \$§ 1001-06, 42 U.S.C. \$§ 1201-06 (1965); Aid to Families with Dependent Children. Social Security Áct of 1935, $\$ \S 401-09,42$ U.S.C. $\$ \S 601-09$ (1965); Aid to the Permanentl: and Totally Disabled, Social Security Act of 1935, \$\$ 1401-05, 42 U.S.C. $\$ \$ 1351-55$ (1965); Ond Age Assistance, Social Security Act of 1935, \$\$ 1-6, 42 U.S.C. \$\$ $301-08$ (1965); Mledical Assistance (Medicaid), Social Security Act of 1935, \$§ 1901-08, 42 U.S.C. \$\$ 1396a-96d (Supp. II, 1965-66); Aid to the Aged, Blind, or Disabled, or for Such Aid and Aredical Assistance for the Aged, Social Security Act of 1935, $\$ \$ 1601-05,42$ U.S.C. 1381-85 (1965).

4. Public assistance is deficient in two critical respects. First, it does not reach 83 per cent of the poverty-stricken families, and, of those who do receive benefits, almost all (five out of six households) are still below poverty lines after the benefits are counted. Second, it imposes restrictions and conditions that encourage continued dependency on welfare and undermine self-respect and family stability. See Orshansky, The Shape of Poverty in 1966, 31 Soc. SEC. BuLL, March, 1968, at 3, 28-29; Income Mfaintenance Hearings 108.09; R FIMAN The Poorhouse STATE (1968); W. BeLL, AID to Dependent CIILREN (1965); Reich, Individual Rights and Social Welfare: The Emerging Legal Issues, 74 YALE L.J. 1245 (1965); tenBroek, Califormia's Dual System of Family Law: Its Origin. Detelopment and Present Status (pts. I-III). 16 STAN. L. REv. 257, 900 (1964), 17 id. 614 (1965).

See also HuNGer, U.S.A., supta note 2, at 70-76; SOUTHERN REGIONAL Counch, PUDLIC ASSISTANCE IN THE SOUTH (1966). 
time, the deficiences of present welfare measures have turned attention to bolder ideas ${ }^{5}$ - the boldest and most seriously considered being the negative income tax (NIT). ${ }^{\circ}$

Any national income maintenance program should not only assure everyone a minimum standard of living but should also attempt to integrate the poor into society. ${ }^{7}$ In light of the distasteful experiences with public assistance and other anti-poverty efforts, the NIT with its direct cash payments scaled to need alone seems the simplest and quickest way to welfare objectives. Whether the NIT can succeed in alleviating and eventually eliminating poverty, however, may depend upon the proper solutions to a number of complex problems of policy and administration. The model statute set forth here attempts to deal directly with these problems, to suggest what the proper solutions may be, and to indicate what an effective negative income tax would entail.

5. Recent income maintenance proposals are surveyed briefly in Nicol, Guaranteed Income Maintenance: Another Look at the Debate, WELFARE IN REviEW, Junc-July 1967, at 1 , and in Schorr, Alternatives in Income Maintenance, 11 Socint WoRk 22 (1966). Many income transfer schemes are presented and discussed in C. GreEN, NeGative Taxes

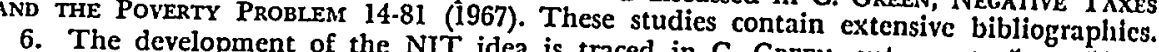
"Negative income tax" has the NIT idea is traced in C. GREEN, supra notc 5, at 51.61. tax, we mean our own proposal of the better. When we refer to the negative income plan is closest to Tobin, Pechman the better-known income maintenance proposals, our 77 YALE L.J. 1 (1967). The similarities amongi, Is a Negative Income Tax Practicall emphasized in C. GREEN, supra note 5, at 62.67.

The widespread interest in the NIT is indicated by President Johnson's reference to it in the ECONOMIC REPORT OF THE PRESIDENT, 1967, at 17 and by his appointment in January
1968 of a Commission on Income Maintenance to than 1228 economists at 143 institutions of to study the NIT and related idcas. More proach to income maintenance, and dorsement also. Income Maintenance Hearing House Conference gave its tentative en. See, e.g., Statement of Maintenance Hearings 452, 676. The NIT has its critics, however. Hearings 658; Vadakin, A Critique Association of Manufacturers, Income Maintenance INTEREST, Spring 1968, at 53; Schorr, supra note 5; Statement ofnihan, The Crises in Welfare, id., Winter 1968, at 3;

7. The NIT seeks to integrate the poor into Income Maintenance Hearings 212.

poor to seek and retain employment. For the unemploty by encouraging the cinployable them, without injuring their dient. For the unemployable poor, the NIT secks to provide adequately. Any NIT program hopes that the of living will strengthen family enable people to function as productive members of society. programs thwarts the development of self-reliance society. The present public assistance service and counselling. These conditions oftence by conditioning grants on accepting behavior. See pp. 281-82 infra. Nonetheless, these become devices for controlling recipient guage that declares it a purpose of the pubs, these restrictive provisions are couched in lan. ing of the Nation by . . . helping to strengthen assistance program "to promote the well-beindividuals attain the . . helping to strengthen family life and helping necdy families and capable." Social Security Amendments of 1956 , personal independence of which they are The welfare statutes of many INST'NS CODE $\$ 10000$ (West 1966): "With regard for the preservation". CAAL. WELFARE AND ... to encourage self-respect, self-reliance society." 


\section{A Simple Sketch of the Model Act}

The basic notions incorporated into the proposed statute are easily stated. Each family (including single-member households) may claim as a matter of right an income supplement whose amount generally varies only with the family's size. Supplement payments are paid in cash-twice a month or at the end of a year-from the general tax revenues of the federal treasury; the right to start receiving semimonthly payments may be asserted any time during the year. There are no restrictions on how recipients can spend the money and no circumstances under which a family can lose its right to the payments. Once a family elects to receive income supplements, its other available income, comprehensively defined, becomes subject to a special tax at a rate substantially higher than corresponding income tax rates. Although members of the family must still pay the federal income tax, these payments are deductible in such a manner that the combined effect of the two taxes never exceeds the special tax rate.

The "special tax" is no real tax at all-it simply operates to reduce the actual government transfer to a family as its income from other sources increases. Otherwise the NIT benefit would be the same for the well-enough-off as for the truly poor. Under the proposed statute, the annual income supplement for a family of four is $\$ 3200$-a figure which closely approximates the Social Security Administration's poverty index ${ }^{8}$ - and the special tax rate applicable to the family's other available income is 50 per cent. When the family's unsupplemented income is twice its supplement, or $\$ 6400$ a year for a family of four, the family will "break even" in terms of obligations to and from the federal government under the positive and negative tax programs. Just above the break-even point, the family will still benefit under the NIT pro. grams, but the benefits will only partially offset positive income tax liability. As unsupplemented income increases further, it will reach a point at which the family's special tax liability alone equals the amount of the income supplement. Beyond this "tax break-even point" $\$ 7916$ for a family of four ${ }^{10}$ - there is no advantage in being under the NIT program.

8. For a discussion of how these guarantee levels were selected. See p. 298 infra.

8. The term was originated in Tobin, Pechman \& Mieszkowski, supra note 6, at 7.

10. This income figure and the accompanying table are calculatcd by assuming that adjusted gross income (AGI) is equal to the sum of the comprehensively defined "avilable income" of the statute, plus twice the federal income tax on the AGI (an amount deducted in computing "available income.") See Income Supplement Act $\$ \$ 10,11$, p. 315 


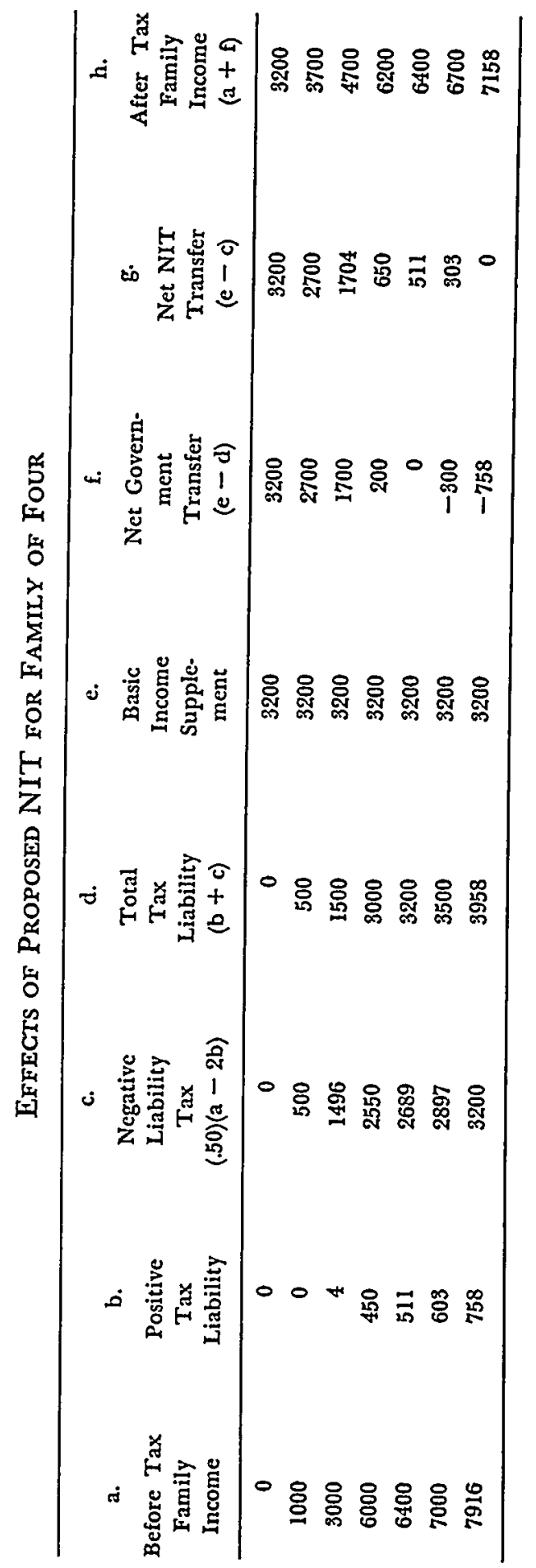


Because of the NIT's tax-like features and also because of the need to make a clear break with past welfare administration, the proposed statute entrusts the program to a newly created agency within the Treasury Department, the Bureau of Income Maintenance."1

\section{Problems of Drafting: Policy Conflicts and Choices}

On its face, the proposed statute may appear to operate smoothly, but most provisions represent uneasy compromises between inconsistent policies. The goal of the model statute is to guarantee an adequate income to everyone while at the same time preserving the incentive to work among recipients, protecting their rights and dignity, treating equal needs equally, and guarding against abuse and fraud-and to do all this at a reasonable cost and without impossible burdens on administration. Yet it is difficult to protect the dignity of the recipients and at the same time police for abuses, to respond equally to equal needs and also avoid an administrative morass, or to remove financial incentives to family splitting without departing from standards of need. It is especially difficult to establish a realistic supplement level and a tax rate that will not destroy work incentives without exceeding reasonable bounds of cost. ${ }^{12} \mathrm{~A}$ brief discussion of work incentives, the overall cost of the program, and the NIT's impact on family structure will demonstrate the severity of the conflicts involved in drafting the statute.

\section{A. Work Incentives, Income Guarantees, and Program Cost}

What effect the model statute would have on work incentives is unknown; the problems can only be raised. ${ }^{13}$ The work-incentive goal of the statute is two-fold: to minimize labor force drop-outs and to avoid unduly impairing the potency of wage gains as incentives for

\footnotetext{
infra. Since available income will almost always be langer than AGI (although it is difficult to estimate by how much), the figure of $\$ 7916$ should really be vicwed as a is difficult to estimate by how much), thilies of four. If the available income of a family of four exceeded AGI by $\$ 1000$, for example, the tax-break-even point measured in terms of AGI would be only about $\$ 6700$. If we assume that on the average available income will exceed AGI by 10 per cent, then the average tax-break-even point measured in terms of AGI will be roughly $\$$ s6900.

11. See Income Supplement Act $\S 20$ and accompanying comments infra.

12. See Vadakin, supra note 6, at 53. See also C. GREEN, supre note 5, 3t 62.81.

13. See the discussion in C. GREEN, supre note 5, at 113.37. The Office of Economic Opportunity is presently funding an experimental NIT project in several New Jersey cities. The project should be the source of valuable data on the incentives question. N.X. Times, Oct. 27, 1968, at 52, col. 4 .
} 
intraplant advancement and for geographic and interplant mobility of workers.

An income maintenance program which seriously reduced participation in the labor force would be unsatisfactory from several standpoints. Such a program would thwart the goal of integrating the em. ployable poor into the rest of society and would compromise general economic goals of growth and increasing production. Certain sectors of production would particularly suffer from a decline in the supply of unskilled labor, and differential drop-out rates in various occupations would have a disrupting effect on the present wage structure in the economy.

A statutory work requirement would "solve" the drop-out problem, 14 but at the cost of the recipients' independence and dignity. The alternative is to rely on financial incentives to keep recipients in the labor force and responsive to labor market economics. How effective these incentives will be depends on both the NIT guarantee levels and the special tax rate. If the guarantee levels are high, a very low special tax rate might not be enough to prevent substantial labor force drop-outs. The supplement levels proposed here are already the minimum incomes set by the Social Security Administration poverty lines, so it would defeat the major objective of the program to reduce them. The problem then becomes one of selecting the appropriate tax rate.

A special tax rate approaching 100 per cent would have a severe drop-out effect. Since there are few non-financial rewards for low-wage employment, almost no one participating in such a program would take a job unless he could earn an after-tax income substantially greater than his family supplement level-perhaps $\$ 4000$ a year for a family of four. Experience in the public assistance program with reducing benefits dollar-for-dollar as earned income increases has indicated the anti-employment consequences of this system.

A very high tax rate would also severely interfere with the labor market's efficient allocation of those NIT recipients who continued to work. If workers retained only a small fraction of the increased wages they would gain through promotion or by moving to a new plant or geographic region, their sensitivity to wage differentials would probably decrease sharply. Moreover, a high special tax rate might pressure

14. See 42 U.S.C.A. $\$ \& 602(a)(19)(A)$ to $-(F), 607(b)$ (Supp. 1968). Such a policy can be carried to extremes. The New York Court of Appeals reversed the criminal conviction of a welfare recipient for refusing to accept a low-paying job. People v. Pickett, 19 N.Y.2d
170,225 N.E.2d 509, 278 N.Y.S.2d 802 (1967). 
workers (and unions) to demand higher wage increases to offset the high rate, thus increasing the cost-push inflationary pressures in the economy.

Any lowering of the special tax rate, of course, reduces the incentive to drop out of the labor force by increasing the portion of earned income a family may retain. A lower tax also increases workers' willingness to move or to seek advancement in order to obtain higher wages. These effects on work incentives are likely to be disproportional to the financial gains to the individuals involved, since the retained earnings will represent the family's first really discretionary income, ${ }^{15}$ and the family will be able to plan its consumption against the background of a secure income. Thus at the other extreme from the 100 per cent rate, a special tax rate approaching zero, with the supplement levels proposed here, would probably cause very few people to leave the labor force and have only minimal effects on the operation of labor markets. As the special tax rate is lowered, however, two complications arise. First, the location of the tax break-even point is inversely related to the tax rate, so that participation in the program increases sharply as the rate is lowered. Second, as participation increases, so does the cost. A program with a near-zero tax rate, for example, would cost over $\$ 150$ billion a year if-as is likely-almost every family in the country elected to receive supplements.

The 50 per cent tax rate proposed in the model statute represents an attempt at compromise between the labor market and budgetary effects, although the result of the compromise may be that neither incentive nor cost goals are fully attained. ${ }^{16}$ From the standpoint of the work incentive alone, the 50 per cent rate may still be too high. Over the lower ranges of earned income, it is a higher tax rate than the 1967 Social Security amendments impose on present public assistance recipients. ${ }^{17}$ Even assuming no serious drop-out problem at this rate, however, the impact on the labor market of this NIT program may be substantial. Combined with the poverty-line supplement levels, the $\mathbf{5 0}$ per cent rate produces a tax break-even point of almost $\$ 8000$ a year

15. Cf. Ayres, Guaranteed Income: An Institutionalist View, in TuE Guarasteed INCOME 173-74, 176-77 (R. Theobald ed. 1967); Income Mainlenance Hearings 324.

16. A 50 per cent rate has been discussed by several prominent cconomists. See, efs., Tobin, Pechman \& Mieszkowski, supra note 6, at 4. Also, officials operating the New Jersey experiment, see note 13 supra, believe that the 50 per cent rate has the best chance of success. Lecture by Harold Watts, Director, Institute for Research on Porcrty of the University of TVisconsin and Consultant to the New Jersey experiment, at liale University. November 14, 1968.

17. 42 U.S.C.A. $\S 602(a)(7)(A)$ (Supp. 1968) (exempting the first $\$ 90$ per month of carned income plus one third of the remainder). 
for a family of four. ${ }^{18}$ Consequently, at least half the labor force would benefit from the NIT and be brought under the special tax..$^{10}$ This high marginal tax rate (relative to present positive tax rates) on such a large portion of the labor market could severely affect the financial incentives of a great number of workers, neither poor nor near-poor.

Finally, the 50 per cent tax rate means that the cost of the program will be substantial-very roughly, $\$ 27$ billion, after account is taken of the savings that would result from the elimination of state and federal public assistance payments. ${ }^{20}$ Because of the relatively high tax break-even point, much of this money will be distributed to the nonpoor. The wide coverage also increases administrative costs, both because the number of beneficiaries is greater and because the difficulties in determining "available income" increase with greater wealth. The $\$ 27$ billion estimate may well be exaggerated, because the 1966 data on which it is based make use of a definition of income less comprehensive than available income as defined in the model statute and because personal income per capita has risen since 1966. But even after these corrections are made, the NIT as proposed may be too expensive for many Congressmen. The cost could be reduced substantially by certain minor changes in the NIT program which can be justified in terms of policies (aside from economy) discussed below."1 But larger savings would require either a higher special tax rate (with the resulting labor market effects), guarantee levels generally below the poverty lines, or both.

\section{B. The Family Unit and Guarantee Levels}

The second major confrontation of conflicting policies takes place over the determination of what should be the unit to receive NIT bene-

18. See table, p. 271 \& note 10 supra.

19. See Orshansky, The Shape of Poverty in 1966, supra note 4, at 3, 19.

20. This calculation is based upon family income statistics to be found in BUresu or the Census, Current Population Reports, income in 1966 of Families and Persons in the United States, Series X P-60, No. 53 (1967). Unlike income statistics from income tax returns, these data include government transfers in income.

The NIT's potential for lowering administrative costs has probably been exaggerated. First, although the NIT statute has been designed to replace public assistance, some functions that public assistance presently performs would have to be continued, and perhaps they should be administered by a residual public assistance burcaucracy. See pp. 281.82 infra. Second, the cost of administering the NIT itself could be substantial. Sce, c.g., Income Supplement Act $\$ 20(\mathrm{e})$ infra (authorizing the establishment of local offices of the Bureau of Income Maintenance).

21. For example, if the supplemental level for an unrelated individual was lowered from $\$ 1200$ to $\$ 1000$ per year and certain economies of scale for familics with several dependents were recognized, perhaps $\$ 5$ billion could be shaved off the present estimate, Tobin, Pechman \& Mieszkowski, supra note 6, at 8.9; Tobin, Raising the Incomes of the Poor, in AGENDA FOR TTE NATION (K. Gordon ed. 1969). 
fits. Like most income maintenance plans, the model NIT uses family units, instead of individuals, as the bases for calculating need and disbursing benefits. ${ }^{22}$ Given the assumption that the NIT should guarantee only a minimum standard of living to every family, using the family as the basic unit makes very good sense. When a person belongs to a family group which pools its resources and shares expenses, his standard of living depends on the total income available to that group and not merely on his own. ${ }^{23}$ Moreover, the larger the family, the less per capita income it apparently needs to maintain a particular standard of living.24 If an NIT program is going to take family economies into account, it vastly simplifies administration to deal with families as a unit.

The decision to focus on the family and to adjust supplement benefits according to family size, however, reflects popular moral notions and the need to contain the cost of the NIT as well as more technical economic, administrative, and welfare considerations. Providing all recipients with a basic grant adequate for the needs of a single individual and then letting them enjoy any savings realized by marriage or living together would be far less troublesome to administer; but the statute rejects this alternative-partly because it would greatly increase the cost of the NIT and partly because few people agree that the government should give the poor more than they absolutely need.as The positive income tax, reflecting not so much a different public morality as a different class of beneficiaries, takes the opposite tack. It not only ignores family economies, it contributes to them through such devices as joint filing. ${ }^{26}$

The basic income guarantee provisions of the model statute are generally based upon the poverty levels determined by the Social Security Administration. ${ }^{27}$ The family unit is entitled to receive $\$ 1200$ For the first claimant, $\$ 800$ for the second claimant, and $\$ 600$ for each lependent. ${ }^{28}$ More than two claimants in a family unit are not allowed.

22. See generally Tobin, Pechman \&: Miesckowski, supra note 6, at 8.10 (1967); (. GrEEN, supra note 5, at 99-105 (1967). In Canada, the Royal Commission on Taxation 1 is recommended a shift from the historic focus on the individual to the family as the 1 oper taxpaying unit. 3 Royal Comsission on TAxatron, Report (1960).

23. H. Groves, Federal Tax Treatarent of the Family 45 (1963); C. Green, supra I te 5 , at 100 .

24. Orshansky, Who's Who Among the Poor: A Demographic View of Poverly. Soc. 3. BuLc, Juiy 1965, at 8.

25. C. GREEN, supra note 5, at 71; Tobin, Pechman \& Mieszkowski, supra note 6, at 8 .

26. INT. REv. CODE of 1954, \$§ 2, 6013; see Income Maintenance Hearings 281-\$2.

27. See Orshansky, Counting the Poor: Another Look at the Poverty Profile, Soc. SEc iv L., Jan. 1965, at 3, 9.

:8. Income Supplement Act \& 5(a) infra. 
Dependent allowances do not taper off because of the harsh effect this would have on large families. The Social Security Administration index suggests that for each minor dependent, a family requires $\$ 600$ a year to maintain its standard of living. ${ }^{20}$ The absence of a limit may encourage child-bearing or at least fail to discourage it, but consigning large families to a subminimum standard of living is an inappropriate means for implementing birth control..$^{30}$

The supplement guarantees deviate deliberately from the poverty line in one respect. Studies indicate that a single individual, living alone, needs about 70 per cent as much for a minimum adequate income as two people living together. ${ }^{31}$ Thus, if $\$ 2000$ a year is a minimum income for a couple, a single claimant should receive $\$ 1400$, and the second member of the family unit, whether a claimant or depen. dent, should increase the family's supplement just $\$ 600$. Setting up the guarantees in this way, however, would create an $\$ 800$ incentive for a family to break up-either in fact or in form. Paying a family unit only $\$ 1200$ for the first claimant and $\$ 800$ for the second is an attempt to minimize this effect. ${ }^{32}$ Furthermore, more than half of the single member family units are old people, ${ }^{33}$ who frequently receive benefits from both Social Security and Medicare, have a special priority in admission to public housing, and otherwise need less income. Payments of $\$ 1000$ for every claimant would remove any incentive for the family unit to split, ${ }^{34}$ but this solution seems too great a deviation from the poverty line for single individuals.

29. See Orshansky, The Shape of Poverty in 1966, supra note 4, at 4.

30. There are sound arguments that the setting of a maximum grant per fanily, there. by discriminating against large families, would be unconstitutional. See Collins v. State Bd. of Social Welfare, 248 Iowa 369,81 N.W.2d 4 (1957); Metcalf v. Swank, 97 U.S.L.W. 2276 (N.D. Ill. Nov. 12, 1968).

31. Estimates of the income required by a single individual living alone relativo to a married couple range from an empirically observed 60 per cent for middle-income familles to an estimated 80 per cent for low-income families. See Revised Equivalence Scale for Urban Families of Different Size, Age and Composition, to be published as U.S. DEr'T of Labor, Bureau of Labor Statistics, Bull. No. 1570-2; Orshansky, Who's Who Among tho Poor, supra note 24 , at 9 . Seventy per cent has been chosen as a reasonably safe cstimate.

82. See also p. 280 supra.

33. Orshansky, The Shape of Poverty in 1966, supra note 4, at 4.

34. Some writers have urged this solution. Tobin, Pechman \& Mieszkowsk1, supro note 6 , at $8-9$. Instead of setting equal benefit levels for the two adults in a family to avoid the incentive to split, the single individual's benefit level could be left at it highe level, individual filing retained, and a provision added to restrict each married couplo $t$ only one "head of household" allowance between them whether they filed scparately a jointly. See H.R. 17331, 90th Cong., Ist Sess. (1968). Thus, while husband and wife coul file separately, they would not obtain an increased benefit level. This approach on transfers the point of tension; there would still be an incentive to be unmarried becau then the man and woman would be entitled to two "head-of houschold" allowance Secondly, this approach permits the wage-earner to file separately from his family, thorel multiplying administrative and calculation problems in taxing transfers from the wag earner to his family. 
Since they can receive more money under the model statute if members file separately, families are not likely to appreciate the reasons for unit filing enough to do it voluntarily. Also, in many families most of the income is attributable to only one member: by filing separately, the rest of the family could receive income supplements while the wage earner evaded the offsetting special tax obligation. The statute must therefore make a certain amount of unit filing legally unavoidable. ${ }^{35}$ First, minors - unless they are married, or over eighteen and no longer in school or supported by their parents-cannot claim an income supplement under the program: they may receive benefits only indirectly, as someone else's dependent. ${ }^{36}$ Second, married couples, as well as unmarried couples who live together and are the common parents of at least one child, must file as a single family unit. ${ }^{37}$

The logic behind the mandatory family unit requirement, of course, extends to all groups sharing the same dwelling unit. Economically, there is no difference between a married and an unmarried couple living together, and even roommates of the same sex can live substantially more cheaply than a single person. Yet, however necessary, the requirement is a serious troublemaker, and extending its scope would only multiply problems of enforcement and administration. ${ }^{38}$ Unlike marriage and parenthood, more informal relationships leave little documentary evidence of their existence and are generally transitory. Finally, adding to the number of situations in which a group had to file together would imply a much broader duty among recipients to share their income with others than that imposed by state support laws. ${ }^{39}$ Since the statute has no provisions to enforce the duties of support it assumes, nothing would prevent a claimant in such a case from withholding benefits from dependents, or from the other claimant. More important, imposing any extra duty of support on a recipient violates the statute's clear policy against placing special burdens on the poor as a condition of their receiving benefits. ${ }^{40}$ Consequently, the statute specifically limits the duty of support imposed on adults in required family units to that imposed by state law.

35. See Tobin, Pechman \& Mieszkowski, supra note 6, at 9.

36. Income Supplement Act $\S 9(\mathrm{~b})$.

37. Id. $\$ 9(d)$.

38. See, e.g., Reich, Midnight Welfare Searches and the Social Security Acl, 72 YalE L.J. 1347 (1963); cf. King v. Smith, 392 U.S. 309 (1968).

39. TenBroek, California's Dual System of Family Law: Ils Origin, Development, and Present Status, 17 STAN. L. Rev. 614, $650-58$ (1965); see, e.g., CAl. Civil Code \& 209 (1954). 40. Id. But see Lewis \& Levy, Family Law and Welfare Policies: The Case for "Dual Systems," 54 CaLIF. L. REv. 748, 759 (1966). 
Although the mandatory family unit provision is generally consistent with the duties of support defined by state laws, ${ }^{41}$ it still cannot ensure that income earned by one member of the family is available for the support of other members. The statute plainly intends that claimants support dependents out of their own income as well as out of supple. ment payments; 42 if one claimant refuses, however, the other's inability to file separately severely undercuts the NIT's antipoverty objectives. Parents of a minor who refuses to pool his earnings ${ }^{43}$ can at least avoid reporting the money as family income by not claiming him as a dependent. Where a wife or child is not getting a share of a husband's income, the mandatory filing provision leaves them only what comfort they can find in state support and neglect statutes.

Even when all members of a family are willing to pool their resources, the mandatory unit filing rule, coupled with graduated supplement levels, encourages them to feign separation and non-support. Policing for such fraud will place another burden on NIT administration and invite the revival of such bureaucratic abuses as midnight searches. ${ }^{44}$ Moreover, while the provision might not actually break up families, it does create undesirable tensions. ${ }^{45}$ An unmarried couple, living together, would be reluctant to legalize their relationship, and, if they had a child, the father might leave rather than relinquish his status under the program as a separate filing unit. Society esteems a stable family unit built around a legitimate marriage:46 whatever harmful effects the proposed statute would have upon the family structure of recipients weakens its effectiveness as a means to integrate the poor into the rest of society.

By limiting to $\$ 400$ the difference between income supplements for the first and second claimants in a two-claimant family unit, the statute attempts to relieve the pressures on the required family units, lessening the incentives either to break up or to cheat. This adjustment does not

41. See Income Supplement Act $\$ 9(f)$ infra. See also King v. Smith, 392 U.S. 909 (1968).

42. Because the NIT imposes a 50 per cent tax rate, a wage earner included in an NIT family unit is actually required to contribute only one half of his earnings to support the rest of the family unit.

43. Cf. Bittker, Income Tax Reform in Canada, 35 U. CHI. L. REv. 687, 648-49 (1968).

44. See note 38 supra.

45. The rewards are probably not great enough to cause actual separation in many cases, though this is a problem with present welfare programs, which withhold all benefits from families with an employable male head. Cf. W. BELL, AId TO DEPENDENT CHILDREN 129 (1965).

46. Gibbard, Poverty and Social Organization, in PovertY AMID AFFluence 45 (L. Fishman ed. 1966); C. GreEN, supra note 5, at 103.04; see R. Tirmuss, Prontems of Sociat Policy 171-83 (1950). 
reduce the incentive for a wage earner to evade the special tax; but by not filing with his family unit, he not only loses $\$ 800$ of income supplement but must also forfeit the benefit of dependency exemptions and joint filing under the positive tax or risk discovery of his fraud. Unless he were receiving approximately $\$ 4000$ income a year, no claimant would benefit substantially by not filing with his family.

\section{The NIT: Competitors and Allies}

While the NIT proposed here should be the core of the national welfare system, it cannot achieve its goals unaided. A comparison with alternative programs-present or proposed-points out the strength and weaknesses of the NIT and suggests complementary strategies for maintaining personal income at decent levels.

\section{A. Public and General Assistance}

In performing the basic function of securing a minimum standard of living, the NIT should be far superior to public assistance. Public assistance has not been successful in maintaining income levels or in fostering social integration, and the proposed statute, explicitly designed as a replacement for public assistance, ${ }^{47}$ reflects in large part the criticisms of present welfare operations. For example, the model statute completely rejects categorical assistance and sets only one criterion for assistance-need; it provides uniform national standards of administration and guarantees adequate benefit levels; it places no restraints on the conduct of recipients or on their use of the benefits; it permits recipients to retain a substantial portion of their other income and assets; and it provides effective remedies to recipients deprived of any of these rights. ${ }^{48}$

Yet public assistance does attempt to perform two important functions which the NIT would not: extending financial aid for health problems and other emergencies, ${ }^{40}$ and providing counselling and advisory services. ${ }^{50}$ Any model welfare system should meet such needs,

47. There is no necessity to repeal explicitly the public assistance portions of the Social Security Act. While NIT benefits will pre-empt the major function of local welfare agencies, these agencies could still continue to administer the programs not pre-empted by the NIT. See p. 282 infra. A preferable solution would be to repeal the public assistance titles and draft new legislation to provide (I) financial aid for medical and other emergencies, and (2) counselling and advisory services. See id.

48. See HAving THE Power, supra note I; Statement of Leslic C. Carter, Jr., Income Maintenance Hearings 2; Statement of Mitchell I. Ginsberg, id. 8.

49. See, e.g., 42 U.S.C.A. \$§ 302-03, 701-14, 606(e)(1) (Supp. 1968). 274.

50. See 42 U.S.C.A. $\$ \S 602(2)(13)$ to -(15) (Supp. 1968); Income Maintenance Hearings 
though the experience with public assistance shows that one program should not try to combine highly personalized services with income grants; the grants tend to become devices for controlling recipient behavior. ${ }^{51}$ Thus, while a residual public assistance supervised by HEW $^{52}$ might initially provide these two special services, eventually advisory and counselling services should be totally separate from emergency financial aid.

If Congress passed an NIT bill with an income guarantee considerably below the level paid by public assistance in some of the more generous states, these states might wish to continue some form of public aid so their welfare recipients would not be left worse off. Public assistance legislation might be integrated into the NIT, as suggested by H.R. $17331,{ }^{53}$ presently before Congress, though this would result in needless duplication and perpetuate the perversities of public assistance. For a more satisfactory, though more costly solution, each state could raise the annual income supplement due its residents up to the old public assistance levels. ${ }^{64}$

A last question concerns the relation between the NIT proposal and the increasingly urgent demands for a wholesale reform of public assistance. Any modification of public assistance programs that took into account all the serious criticisms of present welfare efforts-as, for example, do the recommendations of the U.S. Advisory Council on Public Welfare ${ }^{55}$-would result in a system of distributing benefits strikingly similar to the one outlined in the model statute. The NIT and public assistance reform are not so much alternative ways of dealing with poverty as they are alternative ways of dealing with Congress, and the choice between them is chiefly one of political strategy. Since the NIT completely escapes the faulty concepts and spotted history of public assistance, it still ranks as the preferable approach.

Suggestions for reform of the welfare system have urged that these counselling services be expanded, but be separated from the payment of money. HAving THE POWER, stepra note 1, at $47-66$.

51. See Statement of Leslie C. Carter, Jr., Income Maintenance Hearings 2, 5.

52. See note 47 supra.

53. H.R. 17331, 90th Cong., 2d Sess. (1968), was an NIT proposal introduced in May 1968 by Congressman William F. Ryan (D.-N.Y.) as a bill "to provide for a comprehen. sive income maintenance program." The bill provides for sub-poverty index NIT benefits and a continuation of public assistance as a supplement to the NIT for certain catcgories of persons now eligible for public assistance. See id. \$§ 2-3; Statement of William F. Ryan, Income Maintenance Hearings 354, 356.

54. See Income Supplement Act $\S 6$.

55. Having the Power, supra note 1. 


\section{B. Job Programs and the Guaranteed Job}

Enactment of the NIT should not foreclose continuation and expansion of national job and manpower programs. ${ }^{\circ 0}$ Adult education, job training, job creation, relocation assistance, and local development programs should serve as important allies of the NIT.07 Quite apart from the needs of business, these programs are essential to a comprehensive war on poverty in a society that values employment as a source of income, status, and self-respect. ${ }^{58}$ Moreover, job programs, by lowering unemployment and raising the wages of NIT recipients, would reduce the cost of the NIT program.

A guaranteed job program, insofar as it would further the policy of assuring every American decent employment, is certainly not inconsistent with NIT goals. ${ }^{59}$ The guaranteed job, however, has occasionally been suggested as an alternative to the negative income tax, usually by those who emphasize the conflict between the NIT and the American work ethic. ${ }^{60}$ The most obvious difficulty with this proposal is that at least one-third of all the families classified as poor have no employable members; ${ }^{61}$ more and better jobs is no answer for them. ${ }^{02}$ Yet problems with the guaranteed job do not end there. The guaranteed job plan can be effective only if the government is made employer of last resort. In other words, the government would have to stand ready to employ or to find employment for anyone unable to find a job in the private sector that would lift his family out of poverty. If the guaranteed job

56. These programs and their problems and prospects are described in S. Leviras \& G. Mangum, Making Sense of Federal Manpower Policy (1967); S. Levitan, ANtiroierty Work and Traming EFforts: Goals and RealtTy (1967). See also E. Ginzmenc, Mranfower AGENDA FOR AMIERICA (1968).

57. A more vigorous pursuit of antipoverty goals through these programs has been widely recommended. National advisory Consission on Civil Disonders, Report $413-24$ (1968); Steering CoMmitiee of the ARDEN House Confersnce, supra note 2; Tite NAtional CoMmission on Technology, Automiation and Economic Procress, Techiology AND THE AMrERICAN ECONOMIY 35 (1966). E. FOLEX, THE ACHIEviNc Gherto (1967); Statement of Mitchell I. Ginsberg, Income Maintenance Hearings, 20-21; Statement of Lconard Lesser, id. 199. See also H.R. 12280, 90th Cong., Ist Sess. (1967); A. PenrI ANd F. Reisssas, NEW CAREERS FOR THE POOR (1965).

58. See M. Weber,The Protestant Ethic and the Spirmt of Caritalisar (T. Parsons transl. 1958); Income Maintenance Hearings 128, 297, 397.

59. A guaranteed job program with the government serving as emplojer of last resort was proposed by the President's Commission on Technology, Automation and Economic Progress in 1966. See TEChNOLOGY AND THE AMIERICAN ECONOAIY, supre note 57, at 34. Congressman O'Hara of Michigan introduced a bill in 1967 which called for the undernriting by the federal government of one million jobs, primarily in state and local agencies. H.R. 12280, 90th Cong., Ist Sess. (1967).

60. See, e.g., Statement of Representative Thomas B. Curtis, Income Mfaintenance Hearings 410 .

61. Orshansky, The Shape of Poverty in 1966, supra note 4, at 11 .

62. See id. 
were not to create a gigantic work camp, it would have to offer a range of jobs accommodating a wide variety of skills and interests. Even so, freedom of choice in taking government employment would inevitably be limited, and the program's bureaucracy would have an unhealthy amount of discretion in allocating jobs. Finally, if guaranteed job benefits were substantial enough to keep participants from living in poverty, they would attract many unskilled workers out of low-paying or unattractive jobs in the private sector. Even complicating the administration of the program with a strictly enforced need-foremployment requirement would not significantly reduce the enormous scope and cost of an adequate guaranteed job plan, and the effects on the private sector labor market would be at least as substantial as under the NIT. ${ }^{63}$

\section{G. Programs that Make an Employable-Nonemployable Distinction}

Two arguments encountered in the preceding discussion ${ }^{04}$ push strongly toward a program that, while still comprehensive, would treat the employable and the unemployable poor differently. The first argument is political: that there is little support in Congress for paying an adequate income to people who will not work. ${ }^{05}$ Arguments against such free-handedness range from calling it un-American to a serious concern over the obstacles it would raise to social integration.0 The second argument lies in the conflict between costs and work incentives in the NIT. Arguably, this conflict stems from trying to deal with both the employable and unemployable poor under the same scheme, which must then have relatively high basic guarantee levels for those with no other source of income as well as a relatively low special tax rate to preserve work incentives.

One plan, proposed by Professor James Tobin of Yale, would meet some of these objections by attributing to every employable recipient a presumed income equal to twice his basic income supplement and reducing his NIT benefit accordingly. A person unemployed for good cause would be exempt from the presumption, and as employable

63. See pp. $275-76$ supra.

64. See pp. 276, 283 supra.

65. Senator William Proxmire in an interview with Challenge: Magnzine of Eco. NOMIC AFFAIRs, March-April 1967, at 24. This judgment reflects public opinion at this time. A recent Gallup poll found 62 per cent of the population opposed to a guarantced income plan, while 79 per cent favored a guaranteed work plan. Not surprisingly, lower income groups had larger percentages in favor of both plans. Seventy-threc per cent of nonwhites favored a guaranteed income plan. N.X. Times, Jan. 5, 1969, at 44, col. 1 .

66. See, e.g., Statement of Representative Thomas B. Curtis, Income Maintenance Hearings 410 . 
recipients actually earned income, their presumed income would decrease dollar-for-dollar. Any able adult, except women caring for minors, would ordinarily be considered "employable."

Given this presumption supplement checks might go only to an unemployable member of the family unit, thus in form excluding employable persons from NIT benefits altogether. Since most families would still share benefits with the excluded member, the practical effect of the scheme would be to reduce the supplement level for family units with a non-working employable member. Since the reduced supplement payments, as well as the effective zero special tax rate on all earnings of an employable recipient below his presumed income level, would operate to increase work incentives, the Tobin proposal is primarily responsive to the political objections to the NIT. Because it would not lower the tax break-even point for families with employable members, the presumed-income approach does not prevent participation in the program by families who already have adequate incomes, though it is this overbreadth more than any other feature which drives up the cost of the NIT. In fact, unless the NIT actually had the serious -and unlikely-drop-out effects its opponents fear, Tobin's scheme would save the government almost nothing at all. Except for very low incomes, moreover, the special tax rate would remain the same and create the same disincentives for job advancement.

The proposal for a two-part NIT—one part for families without an employable member and another part for the rest-does meet the objections based on costs and work incentives, though it also embodies a more fundamental departure from the model statute than does Tobin's suggestion. The unemployables' NIT would have supplement levels at the poverty line and a very high special tax, perhaps 75 per cent or higher, while families with employable members would receive substantially lower supplements (about half the poverty level) and face a special tax rate of 33 per cent. A third possibility is to exclude families with an employable member from the NIT entirely, meeting their need through a guaranteed job program instead. ${ }^{.5}$ Of

67. Statement of James Tobin, Income Maintenance Hearings 244. Tobin suggests that the employability category might include all able-bodied persons from 18 to 65 years of age except full-time students and females who are caring for one or more children under 18. He also proposes that a local federal manpower officer certify whether a particular individual's unemployment during a period was for "good cause." The absence of avail. able work due to a recession would no doubt be a justification for unemplojment. Id. 244-45.

68. The AFL-CIO has advocated a similar program package. In his testimony at the Income Maintenance Hearings in June, 1968, Leonard Lesser, General Counsel of the AFL-CIO Industrial Union Department, made the following statement: 
course, some sort of guaranteed job plan would be a necessary corollary of all of these proposals. ${ }^{69}$

The advantages of the last two modifications of the NIT are obvious: they increase work incentives, reduce participation by the non-needy, ${ }^{70}$ and save the program substantial amounts of money. Although the expenses of an expanded job program might offset savings in the NIT, job programs still are more acceptable politically.

Very grave objections, however, lie against any proposal to treat employable recipients less generously. First, there is the difficulty of deciding who is to be treated as employable. A reasonable definition of employability might include all able-bodied persons from 18 to 65 years of age, except full-time students and women caring for children. ${ }^{71}$ While this reflects a natural inclination toward motherhood, it would place a considerable strain on the family structure since only femaleheaded family units could qualify for the higher benefits. The family splitting problem might be so great as to require limiting the high NIT program to the aged, the disabled, and the widowed, though this would take the NIT a long way from its original objectives. Second, there is the problem of dealing with the employable claimant who is unemployed for good cause. Families with such claimants would presumably be eligible for maximum NIT benefits, but defining the limits of good faith unemployment presents almost insuperable problems.

Third, once such lines are drawn, the task of placing individual recipients on one side or the other creates far too many opportunities for administrative error and abuse. ${ }^{72}$ Fourth, the numerous problems

At the core of providing jobs for people is the concept of Government as the employer of last resort, the Government insuring employment opportunities to all workers. ... [I]ncome assistance, no matter what its form, should not be expected to and must not be shaped to, make up deficiencies in either job opportunitics or carning levels. It cannot be a substitute for a decent job at fair wages. It must not bc used to sub. sidize marginal employers, nor should it be expected to bail out a deficient social insurance system. Rather, it should be designed to provide with dignity the basic minl. mum need of those who cannot or should not participate as active members of the work force.

Statement of Leonard Lessor, Income Maintenance Hearings 199, 201-202.

69. Tobin, in particular, is careful to add that his program should be coupled with a federal guarantee of a decent job. Statement of James Tobin, Income Maintenance Hear. ings 245.

70. Although about half the families in the country would benefit financially from the NIT as proposed in the model statute, only a third would find election to their advantage under this two-part NIT program. See Orshansky, The Shape of Poverty in 1966, stupra note 4.

71. This definition is suggested by Tobin in connection with his presumed wages pro. posal. See note 67 supra.

72. A guaranteed job program would simplify the determination of a recipient's employability, but this would not eliminate the risk of error and abuse so much as shift its locus. See note 67 supra. 
with a guaranteed job program must count as a disadvantage of its partial substitution for the NIT. Finally, the two-part NIT would keep in poverty families whose employable members refused to work. Perhaps this program is politically the most feasible, but punishing the children for the sins of the fathers is an unfortunate theme for the attempt to eliminate poverty in America.

\section{Family Allowance}

In family or children allowance plans, the government periodically pays small sums to all families, or at least all families with children. ${ }^{73}$ The payment depends solely on family size or the number of children. The program resembles an NIT with vastly reduced annual income supplements and no special tax. Since the payments go to all families, they could not be generous without making the program prohibitively expensive. In fact, the small payments would subsidize the middle classes and do little to alleviate poverty. Of course, with a more sharply progressive positive tax and a broader definition of taxable income, the family allowance idea would make more sense, but it would then lose its only real strength-political acceptability.

\section{E. In-Kind Programs}

The NIT would insure all families an income sufficient to cover their needs for food, clothing, shelter, and other necessities. The government can also meet these needs directly through programs such as public housing, ${ }^{74}$ rent subsidies, ${ }^{76}$ and food stamps. ${ }^{76}$ In-kind assistance assures that public outlays are actually spent on basic consumption items, but it tends to isolate and spotlight the poor and circumscribe their independence and freedom of choice-both to the detriment of social integration. ${ }^{77}$ Such programs treat only the physical symptoms of poverty while irritating the underlying social and economic causes. If Congress were to set NIT guarantee levels too low to cover basic necessities, in-kind programs would still be necessary; at the guarantee

73. For two articles which reveal something of the Aavor of the NIT, family allowance debate as well as describe family allowance proposals, see Tobin, Do We Want Children's Allowances? THE NEw REPUBLIC, Nov. 25, 1967, at 16; and Vadakin, Helping the Children, ThE NEW REPUBLIC, Dec. 23, 1967, at 15. See also J. Vabafis, ChILDREN of POVERTY AND FaMml Allowances (1968); Moynihan, The Crisis in Weljare, PUBLIC INTEREST, Spring 1968, at 3.

74. 42 U.S.C. $\S 1409$ (1964).

75. 42 U.S.C. \$ 1701 (1964).

76. 7 U.S.C. $\$ \$ 2011-25$ (1964).

77. Cf. HAVING THE PowER, supra note 1, at 72. For criticisms of in-kind assistance, see,

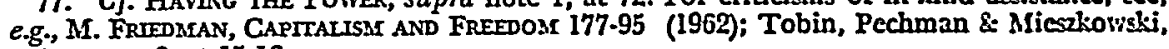
supra note 6 , at $15-16$. 
levels proposed in this statute, however, in-kind programs would continue to have a useful function only in special cases and emergencies.

\section{F. Social Security and Unemployment Insurance}

Although Unemployment Insurance and Old-Age, Survivors, and Disability Insurance play a definite role in alleviating poverty, ${ }^{78}$ their main purpose is to insure against sudden reductions in family in. come. ${ }^{79}$ For the most part, these programs do not duplicate NIT functions and their expansion would be a poor substitute for the NIT. ${ }^{80}$

\section{G. The Minimum Wage}

Insofar as the minimum wage has actually protected the living standard of the worker, passage of an effective NIT would go far to make it obsolete. Such a fate would delight the already numerous critics of the minimum wage, who claim that it places an unfair burden on employers in the less technologically advanced sectors of the economy and threatens the unskilled worker with unemployment. ${ }^{81}$ To the extent that the minimum wage actually raises wages, however, it should shift some of the cost of the NIT from the federal treasury to private employers.

\section{The Statute, Annotated}

The text that follows sets out the proposed Income Supplement Act and explains its provisions. At almost every stage, the problems discussed above reappear. The commentary does not attempt to pick out all of the troublesome points; it would be much too long and redundant if it did. Where the difficulties press hardest, however, the annotation does repeat, in greater detail, explanations that have been outlined elsewhere. Numerous peripheral problems could only be noted briefly.

78. See Orchansky, The Shape of Poverty in 1966, supra note 4, at 26-80.

79. Wickenden, Social Welfare Law: The Concept of Risk and Entitlement, 48 U. DET. L.J. 517, 527-31, 534-39 (1966). See also tenBroek \& Wilson, Public Assistance and Social Insurance - $A$ Normative Evaluation, 1 U.C.L.A.L. REv. 237 (1954).

80. Tobin, Pechman \& Mieszkowski, supra note 7, at 15-16. For a discussion of some of the inequities in Social Security taxation, see Deran, Income Redistributions Under the Social Security System, 19 NAT. TAx. J. 276 (1966).

81. For a brisk discussion of this subject, see, e.g., Lester, Shortcomings of Marginal Analysis for Wage-Employment Problems, 36 AM. EcoN. REv. 63 (1946); Stigler, The Eco. nomics of Minimum Wage Legislation, 36 AM. ECON. REv. 358 (1946); Machlup, Marginal Analysis and Empirical Research, 36 AM. EcoN. REv. 519 (1946). See also Bork, Why $I_{\text {am }}$ for Nixon, The New Republic, June 1, 1968, at 19. 
The statute omits many necessary administrative and enforcement procedures, providing only for those which are of central importance to the model proposal or which pose peculiar difficulties for an NIT program. ${ }^{82}$ In places, the statute disregards administrative difficulties rather than compromise basic policies. The overall aim is to present the essential provisions of a coherent statutory scheme. While none of the difficult decisions embodied in this proposal may be the best that can be made, an explicit presentation and working out of the ramifications of these choices may be of some value to those who seek solutions to the problems of economic deprivation.

\section{TABLE OF CONTENTS}

Section 1. Declaration of Policy .................... 289

Section 2. Short Title .......................... 290

Section 3. Election of Income Supplement ............. 290

Section 4. Supplement Period ....................... 291

Section 5. Family Unit Income Supplement ........... 294

Section 6. Optional State Supplementation ............ 300

Section 7. Special $\operatorname{Tax} \ldots \ldots \ldots \ldots \ldots \ldots \ldots \ldots \ldots \ldots \ldots . . . \ldots \ldots$

Section 8. Annual and Semimonthly Payments .......... 303

Section 9. Family Unit Defined .................. 307

Section 10. Computation of Available Income of the Family

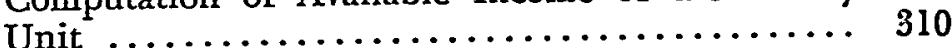

Section 11. Determination of Available Income of Persons .... 311

Section 12. Imputed Income Defined $\ldots \ldots \ldots \ldots \ldots \ldots \ldots \ldots, 321$

Section 13. Capital Utilization Income Defined ........... 323

Section 14. Basis ................................ 326

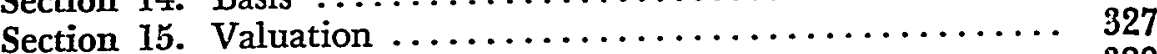

Section 16. Methods of Accounting ................ 328

Section 17. Claims Against Supplement Payments Prohibited 329

Section 18. Records and Returns ................... 330

Section 19. Procedural Rights and Review ............. 330

Section 20. Application of Income Supplement Laws ....... 335

Section 21. Amendments ....................... 337

\section{Section 1. Declaration of Policy}

The Congress declares that the general welfare and security of the nation and the health and happiness of its people require that every

82. For the most part, draftsmen could copy many of the administrative and enforcement provisions needed-regarding returns, sanctions for fraud, etc-from the Internal Revenue Code. In doing so, of course, they should take care not to weaken any of the administrative safeguards provided for recipients under the program. 
family have the right to an adequate income. In a rich and free society, no one need live in poverty, without hope or without opportunity to share the nation's wealth. The Congress finds that present welfare programs cannot assure all Americans freedom from want and that legislation is needed which guarantees to everyone a decent standard of living while preserving individual liberties.

The objectives and policies of this Act shall be to entitle all families to an income supplement as a matter of right, to recognize and protect the personal dignity and legal rights-including the right to privacy -of supplement recipients, to leave recipients free to dispose of supplement benefits as they deem proper, and to encourage the productive employment of recipients by allowing them to retain a substantial portion of earned and other income.

\section{Comment}

The declaration of policy announces two themes which run through every provision of the statute. First, the NIT is an ambitious program aimed at eliminating economic insecurity and deprivation throughout the nation. Its benefits are to be adequate, and in its administration, presumptions should generally favor the recipient over the fisc. Second, the benefits are to be available without restriction, either upon the recipients' use of the money or upon any other aspect of their lives. No official will have discretion to withhold supplements, vary their amounts, or place any conditions upon their receipt.

\section{Section 2. Short Title}

This Act may be cited as the Income Supplement Act of 1969.

Section 3. Election of Income Supplement

(a) Right to Income Supplement.-Every family unit may elect, as a matter of right, to receive an income supplement as defined in sections 5 and 6 of this Act.

(b) Time and Manner of Election.-A family unit shall make an election under subsection (a) -

(1) by filing a final return at the end of the supplement period as provided in section 8(a) of this Act, or

(2) by filing a request for semimonthly payments at any time during the family unit's supplement period, or during the two months preceding such period, as provided in section 8(d) of this Act. 
(c) Effective Period of Election.-An election under subsection (a) shall be effective for one supplement period as defined in section 4 of this Act and cannot be revoked.

\section{Comment}

Section 3(a) entitles every family to participate in the income supplement program, simply by the voluntary application procedures provided in section 3(b). Compulsory enrollment of all family units might have advantages, but it was rejected as an undue constraint on the plan's intended beneficiaries. Where the minor dependents suffer by a refusal to elect under the program, the remedy must lie in the enforcement of child neglect statutes of general applicability. 83 An educational program designed to acquaint potential claimants with their rights under the statute will better deal with the other problems of nonparticipation. ${ }^{44}$

The family unit may elect to participate as early as two months before the beginning of its supplement period and as late as the last day for filing a final return. This assures the marginally indigent family of assistance when it is needed. To ensure that the Treasury's records are current and accurate, elections are effective for only one supplement period and must be renewed for each succeeding period.

\section{Section 4. Supplement Period}

(a) General Rule.-Except as otherwise provided by this section, the family unit's supplement period shall be the taxable year of the claimant or claimants under the provisions of section $441(\mathrm{~b})$ of the Internal Revenue Code of 1954. In the case of a family unit containing two claimants with different taxable years, the taxable year of either claimant may be used unless otherwise required by the Secretary or his delegate. If no claimant in the family unit files an income tax return under the provisions of Chapter 61 of the Internal Revenue Code of 1954, the supplement period of the family unit shall be determined as if its taxable year were the calendar year.

(b) Short Period.-The family unit's supplement period shall be a period less than 12 months (referred to in this Act as a "short period") under the circumstances named in subsections (c) and (d).

83. E.g., CAL. CrvIL CODE $\S 196$ (TVest 1954); id. $\$ 246$ (1963 Supp.); see tenBrock, supra note 4, 17 StAN. L. REv. 614, 651, 682.

84. See Income Supplement Act § 20(c); Income Maintenance Hearings 54-55. 
(c) Terminated Short Period.-A family unit's supplement period shall be terminated in the event that the family unit ceases to exist, or that a claimant, as defined in section 9 of this Act, permanently leaves or joins the family unit, and specifically in the following circumstances:

(1) the claimant, or either claimant of a family unit with two claimants, dies or ceases to qualify as a claimant under the provisions of section $9(b)$,

(2) the claimant, through marriage or otherwise, forms a new family unit under the provisions of section 9 (d), or

(3) two claimants in the family unit cease living together by reason of divorce, legal separation, or informal separation as defined by section $9(\mathrm{e})$.

A family unit's supplement period shall also be terminated in the event that the taxable year of the claimant or claimants used to determine the supplement period of the family unit under subsection (a) is brought to a close under the provisions of section 443(a) of the Internal Revenue Code of 1954. Unless initiated under the provisions of subsection (d), a terminated short period shall begin on the first day of the taxable year used to determine the supplement period of the family unit under subsection (a) in which the terminating event occurred and shall end on the day of the terminating event.

(d) Initiated Short Period.-A family unit's supplement period shall be initiated in the event that the family unit comes into existence, or that a claimant, as defined in section $9(\mathrm{~b})$ of this Act, permanently leaves or joins the family unit, and specifically in the following circumstances:

(1) the claimant or claimants in the family unit become qualified as claimants under the provisions of section 9(b),

(2) the two claimants in the family unit form the family unit under the provisions of section 9(d),

(3) the claimant in the family unit forms the family unit by reason of divorce, legal separation, or informal separation as defined by section 9 (e) by the claimant or by his former co-claimant, or

(4) the claimant in the family unit forms the family unit by reason of the death or disqualification under section $9(\mathrm{~b})$ of his former co-claimant.

A family unit's supplement period shall also be initiated whenever the taxable year of the claimant or claimants used to determine the 
supplement period of the family unit under subsection (a) has been brought to a close under the provisions of section 443(a) of the Internal Revenue Code of 1954. Unless terminated under the provisions of subsection (c), an initiated short period shall begin on the day after the initiating event and end on the last day of the taxable year used to determine the supplement period of the family unit under subsection (a) in which the initiating event occurred.

\section{Comment}

The supplement period is the fundamental accounting period for the NIT. Determination of supplement amounts and application of the special tax both require reference to the supplement period. Present public assistance programs normally have a one-month accounting period, ${ }^{85}$ which allows a recipient to have wide fluctuations in income and still draw benefits when his income plummets. In sharp contrast to this practice, the NIT generally uses a one-year period. The longer period, in effect, imposes a duty to budget and save on low-income recipients. If, for example, an individual has worked at a $\$ 5000$-a-year job for six months, receiving $\$ 2500$ in income, the special tax obligation would wipe out his $\$ 1200$ basic annual supplement. Had he unwisely spent all or most of his income in that time, the NIT would not keep him out of poverty in the ensuing six months. Since poor people may not have the skills or knowledge to budget their finances carefully, ${ }^{86}$ unemployment insurance or a residual public assistance would still have a substantial role to perform in cases of sudden unemployment.

To facilitate verification of NIT returns by comparison with income tax returns, section 4 attempts, insofar as possible, to tie the supplement period of the electing family unit to the taxable year of its members. Most families would in any event follow such a course to avoid additional bookkeeping.

The provision for a short supplement period deviates from the goal of contemporaneous income supplement and income tax records, but it is necessary to avoid serious accounting problems. The provision follows directly from the decision to use the family as the basic accounting unit. The claimant or claimants are the nucleus of this unit. Payments of NIT

85. Income Maintenance Hearings 186-87. Green has suggested the possibility of an income averaging requirement over periods longer than a jear. C. GrEEv, NEGative TAXES AND THE POVERTY PROBLeM 106-08 (1967). But see Tobin, Pechman \& Mieszkowski, supra note 6, at 20. Congressman Ryan's NIT proposal, H.R. 17331, 90th Cong., 2d Sess. (1968). adopted a basic one-month period, but included a provision designed to recoup any monthly benefits paid to individuals who had high incomes on an annual basis. Id. $\S$ 1605 ("Imposition of Tax on Excess Annual Income").

86. See D. Caplovitz, The Poor Pay More (1964). 
benefits are paid to them, and they are responsible for all the duties im. posed by the statute. The income of all members of the family unitwhile they were members of the unit-must be added together in computing the NIT benefits to which the family unit is entitled. Even individual filing of returns would not help to solve the problems associated with changes in the family unit. As long as the incomes of family members are expected to be used to support the family, separate calculations would be required whenever an individual belonged to more than one family unit during a year. Attempting to attribute to an individual various portions of the income earned by the other members of the family unit and attempting to calculate accurately all transfers and income received by an individual would enormously complicate administration. To avoid these complications the statute makes the family the basic accounting unit and terminates a period whenever the family nucleus is altered or dissolved.

When a claimant marries, divorces, or deserts, he leaves one family unit and creates another. For both the old and new family units, a terminated short period facilitates an equitable allocation of NIT benefits and special tax obligations. Moreover, the new electing unit must have a short period if its future supplement periods are to coincide with the taxable year of its claimants. The terminated short period also increases the probability of an accurate final accounting in the event of separation or divorce, where a joint financial statement would be difficult to obtain months later. Finally, when a claimant dies, a terminated period permits a quick settlement of the rights and duties of his estate under the program.

If a claimant's taxable year is terminated under the provisions of section 443(a) of the Code, the family unit's supplement period must end to preserve the compatibility of the two sets of records.

A short accounting period, as noted above, could benefit families with fluctuating incomes, and recipients might sometimes attempt to precipitate short periods. The specificity and formality of the circumstances which terminate a supplement period, however, should help to minimize this problem.

\section{Section 5. Family Unit Income Supplement}

(a) General Rule.-Each electing family unit shall receive as an income supplement for each supplement period of twelve months-

(1) $\$ 1200$ for the first claimant,

(2) $\$ 800$ for the second claimant, and

(3) $\$ 600$ for each dependent-

the sum to be adjusted as provided in subsections (b), (c), and (d).

(b) Short Periods. - If an electing family unit has a supplement period less than a full year, it shall receive as an income supplement for 
such period an amount for each member of the family unit which bears the same relation to the amount provided for such member in subsection (a) as the family unit's supplement period bears to a full year.

(c) Dependents In the Family Unit for Less than a Supplement Period. -If a person was a dependent of a family unit for only a part of its supplement period, the family unit shall receive as an income supplement for such person an amount which bears the same relation to the amount provided for dependents in subsections (a) and (b) as such part of the family unit's supplement period during which he was a dependent bears to the family unit's full supplement period.

(d) Regional and Yearly Variations in Consumer Prices.-

(1) The income supplement of the family unit shall be the amount determined in accordance with subsections (a), (b), and (c), multiplied by a low-income consumer price index for the area in which the family unit resides, as provided by subsection (d)(3). If the family unit resided in more than one such area during its supplement period, the income supplement shall be the weighted average of the amounts determined for each area in which the family established residence. The weights to be used for this determination shall be the fractions of the supplement period during which the family unit resided in each area.

(2) For the purposes of the above paragraph, a family unit shall be deemed to reside in a locality for the period, if fifteen or more days consecutively, that the claimant or claimants regularly occupy a dwelling unit within such locality. Where the claimants in a two-claimant family unit occupy a separate dwelling unit for any period of time, the family unit shall be deemed to reside for such period in the dwelling unit which the members occupy more frequently. For such period of time as a family unit does not qualify as residing in any locality, its income supplement shall be calculated as if this subsection did not apply.

(3) The Bureau of Labor Statistics of the Department of Labor shall establish and maintain a low-income consumer price index based on the retail prices to low-income families of consumer goods and services commonly required by such families, including but not limited to charges for housing, clothing, food, transportation, and retail credit. The index 
shall be so calculated that the national average of low-income consumer prices in the initial year of operation of this Act will have an index value of 1.00 . The Bureau of Labor Statistics shall calculate annually three separate index values for urbanized, urban, and rural areas in each state and territory, as determined by the most recent national census.

(e) Reports by Bureau of Labor Statistics on the Minimum Adequate Standard of Living.-

(1) Within one year after this Act takes effect, and thereafter as often as the Secretary of Labor shall determine necessary to reflect changes in the national standard of living, but no less than every five years, the Bureau of Labor Statistics shall report to the Congress those levels of annual family income which would ensure family units a minimum adequate standard of living, consistent with the national standard of living.

(2) In effectuating the provisions of this subsection, the Bureau of Labor Statistics shall compile and price annual family budgets for all consumer goods and services necessary to a minimum adequate standard of living, including but not limited to -

(A) a diet of sufficient quantities and varieties of foodstuffs to meet those minimum standards of nutritional adequacy which shall be periodically determined by the Food and Nutrition Board of the National Research Council,

(B) housing which meets those minimum standards of safe, sanitary, and decent housing which shall be periodically determined by the Housing Assistance Administration of the Department of Housing and Urban Development,

(C) transportation, either through the use of public transit facilities or through the possession of private means, adequate for travel to and from places of employment, schools, stores, and recreational areas, and for such other activities as are necessary to a minimum adequate standard of living, and

(D) house furnishings, clothing, utensils and appliances, personal care, regular and ordinary medical and dental services, recreation, entertainment, education, and personal communications.

In pricing budget items, the Bureau of Labor Statistics shall take account of certain consumer goods or services provided at a subsidized cost by federal, state, or local government agencies 
only to the extent that these benefits may be received without any showing or declaration of need.

(3) The Bureau of Labor Standards shall compile and price separate annual family budgets for each type of living situation which it determines requires substantially different goods and services, or quantities thereof, for a minimum adequate standard of living; provided, that the Bureau of Labor Statistics shall in any event prepare separate annual family budgets for -

(A) family units living in urban, urbanized, and rural areas, as determined by the most recent national Census,

(B) family units living in regions of the country which, because of climate, regional consumption patterns, or other characteristics, require substantially different goods and services, or quantities thereof, for a minimum adequate standard of living, and

(C) family units which differ in the age and number of their members, except that the Bureau need take into account only such differences in the number and age of family unit members as would require substantial changes in family consumption needs.

(4) The Bureau of Labor Statistics shall price each item in an annual family budget by taking an average of retail prices to low-income consumers for such item in every area to which the budget applies. In determining the average, each price sample obtained shall be weighted by the number of low-income families in the area.

(5) The Secretary of Labor shall prescribe, by appropriate regulations, reasonable and workable procedures for compiling and pricing annual family budgets.

(6) Within ten days after the Bureau of Labor Statistics shall have transmitted its report to the Congress, pursuant to subsection (e)(1) of this section, the Secretary of Labor shall cause a copy of that report, together with copies of the annual family budgets on which it is based, to be published in the Federal Register.

(f) Recommendations of the Secretary of the Treasury.-Within sixty days after the Bureau of Labor Statistics shall have transmitted its report to the Congress, pursuant to subsection (e)(1) of this section, the Secretary or his delegate shall prepare and transmit to the Congress recommendations specifying how the provisions of this section, including the income supplement guarantees in subsection 
(a), might be amended to reflect the findings of the Bureau of Labor Statistics.

\section{Comment}

The supplement levels in section 5(a) generally reflect the poverty line drawn by the Social Security Administration: about $\$ 3200$ a year for an average urban family of four. ${ }^{87}$ The SSA poverty line-the "minimum money income required to support an average family of given composition at the lowest level consistent with the standard of living prevailing in this country" 88 - has gained wide acceptance. ${ }^{80}$ Actually, it is a very rough estimate, based on the cost of an "economy" food plan developed by the Department of Agriculture and on the percentage of income the average American family spent on food in $1959.0^{\circ}$ Not only has the "economy" food plan been sharply criticized as inadequate, but the SSA definition also relies on the unlikely possibility that low income families can economize on other necessities to the same extent as on food. ${ }^{01}$ It may mensure need too crudely for families whose living situations change significantly with a few hundred dollars more or less income a year.

87. The Social Security Administration (SSA) poverty guidelines are presented in Orshansky, The Shape of Poverty in 1966, supra note 4, at 4. The guidelines vary for families depending on (1) family size, (2) age of head (over 65 or under), (3) sex of head, and (4) farm or nonfarm residence. The variations based on residence, age, and sex of family head were not adopted, since they are based on the failure, not relevant herc, to take home-grown food and capital holdings into account in calculating family income. See Orshansky, Who's Who Among the Poor: A Demographic View of Poverly, 28 Soc. SEC. BuLl., July 1965, at 8-10, 13. The budget levels specified in section $5(a)$ thus most closely parallel those for non-farm families without an elderly head. The information to be collected in connection with section $5(e)$ of the proposed statute should be helpful in determining if the deleted distinctions or any others should be reintroduccd.

88. Orshansky, Who's Who Among the Poor, supra note 87, at 8 .

89. The SSA index has been adopted by the Office of Economic Opportunity as its official measure of poverty for funding its programs.

90. American families on the average spend 33 per cent of their income on food; the poverty line is thus established by multiplying the cost of the economy food plan by three. See generally Orshansky, Counting the Poor: Another Look at the Poverty Profile, 28 SOC. SEC. BULL., Jan. 1965, at 3-29.

91. Rose Friedman has noted, without evaluating the accuracy of the SSA poverty lines, that the poor spend considerably more than 33 per cent of their income on food. Friedman, The Official Estimates are Wrong, in POVERTY AMERICAN STYLE 106, 109 (H. Miller ed. 1966). Mollie Orshansky has argued that the estimate is falrly accurate. Orshansky, Who's Who Among the Poor, supra note 87, at 8-9. In either event, conclusions drawn from the percentage of income the poor in fact spend on food have little, if any, relevance to a determination of what they need to spend on food and other items. See also How Much Is Enough? A Note on Poverty Budget, in POVERTY IN AMERICA 39-42 (L. Ferman, J. Kornbluh \& A. Haber eds. 1965); R. Friedman, supra note 90; Income Maintenance Hearings 140, 538.42. Edward Sparer of the Yale Law School is presently working on studies which show that the minimum income necessary for an adequate standard of living is at least $\$ 6000$ for an urban family of four. If this figure does reflect the proper poverty line, the arguments in favor of an employable-unemployable distinction grow stronger. In order to provide adequately for the unemployable poor at these levels whilc retaining some work incentive, the cost of the NIT's work incentive would have to be kept as low as possible, perhaps by restricting its coverage to a defined group of employable poor. A tax rate higher than the 50 per cent proposed in the model statute might also be required. 
One of the primary thrusts behind the NIT (and all welfare reform proposals) has been the desire to set one national standard of need and adhere to it. Yet costs of living vary substantially in different regions of the country, as well as between urban and rural areas. One thousand dollars will buy many more goods and services in the Mississippi delta than in New York City. If the statute simply set one national allowance schedule for various family sizes, it would create an incentive to live in rural areas and in sections of the country with low costs of living, such as the South. Furthermore, one national allowance schedule without a cost-of-living adjustment would produce a substantial redistribution of income among regions of the country; substantially more NIT benefits would go to the South if there were no cost-of-living adjustment than if there were such an adjustment. On the other hand, the substantial advantage of one national allowance schedule with no variation is the relative ease of administration. No matter where a family unit was in the country, it would receive the same benefits, depending solely on its size. Moreover, equal benefits would tend to relieve congestion and excess demand in urban areas.

Despite the serious administrative complexities involved, section $5(\mathrm{~d})$ provides for a low-income retail-price index to adjust the basic income supplement. The index would require separate calculations in each of the fifty states for the three types of areas currently distinguished by the Census Bureau-urban, urbanized, and rural-or 150 different index compilations (plus index compilations for the territories). Income supplements would be adjusted according to where a family unit lived, and the amount of the supplement would change when a family unit moved from one area to another.

Administrative difficulties may make this proposal unworkable, but even if these distinctions are too fine, some cost-of-living adjustments seem necessary, particularly since the SSA poverty lines represent such minimal and rough estimates of need. An intermediate suggestion would be to make cost-of-living adjustment on a state-by-state basis. Section $5(e)$ directs the Bureau of Labor Statistics to provide Congress with the additional information necessary to set and maintain supplement levels as precisely as desired. With the assistance of other government agencies having expertise in such fields as nutrition and housing standards, the Bureau of Labor Statistics will itemize the goods and services vital to a minimum adequate standard of living. Since both family needs and the general standard of living vary from urban to rural environments and from region to region, subsection (e) requires that these, as well as any other relevant factors, figure in the determination of a minimum standard of living for a family unit. The result of these studies will be a series of annual family budgets which, when priced, will draw much more clearly the boundary line of poverty. ${ }^{82}$

92. Cf. M. Harrington, The Other America: Poverty in the Untred States 179 (1962); How Much is Enough? supra note 91; Lamale, Poverty: The Word and the Reality, MO. LAB. REV., July 1965, at 822 . 
The statute does not specify precisely what use the Government should make of this new information: the basic intention is to give Congress and the country a feel for the national profile of poverty. Even if the new information indicates a need for very fine distinctions (for example, that entirely different budgets are necessary for different regions of the country), the administrative difficulties involved may be too great. Nevertheless, after the Bureau of Labor Statistics has prepared the budgets and tables of figures, Congress will be able to adjust the income supplement levels with considerably more accuracy than at present. Moreover, the publication of the Bureau studies should put some pressure on Congress to act.

Congress could revise supplement levels with less administrative trouble and expense on the basis of periodic recalculations of the SSA poverty index. The Bureau of Labor Statistics, however, will already be doing much of the work required by subsection (e) in constructing the low-income price index required under subsection (d). In addition, the Bureau has long been preparing standard family budgets ${ }^{33}$ - though not on so broad a scale-and is presently compiling a budget for a minimum adequate standard of living. .4 Finally, the price of ignoring substantial variations in the cost and standard of living, and thereby overpaying and underpaying large classes of recipients, seems higher than the administrative expense of subsections (d) and (e). ${ }^{95}$

\section{Section 6. Optional State Supplementation}

(a) State Election of Increased Income Supplements.-A state may elect, by appropriate legislation, to have additional income supple-

93. U.S. Dept. OF Labor, Bureau of Labor Statistics, Workers' Budgets in the United States: City Families and Single Persons, 1946 and 1947, Bult. No. 927 (1918); U.S. Dept. OF LABOR, BUREAU OF LABOR Statistics, RePORT OF the Advisory CommitteE on Standard Budget Research 8 (June 1963).

The budgets, first developed in 1947, consist of a detailed list of goods and services required by a typical middle-class family of four. In their present form the budgets arc a combination of items required to meet acceptable standards of adequacy in food and housing and those discretionary items which consumer surveys show most pcople in fact purchase.

The latest standard budgets to be prepared are: U.S. DEPT. of LABOR, BUREAU of LAdor Statistics, Butc. No. 1570-1, City Worker's Family Budget for a Moderate Living Standard (1966); id., Bull. No. 1570-4, Retired Couple's Budget (1966).

94. The lower standard budget, representing a minimum standard of adequacy, has been in preparation for a considerable time. See City Worker's Family Budget for a Moderate Living Standard, supra note 93, at vii. Indications are that it should be published sometime in the near future. Conversation with Helen Lamale, Chief of the Divi. sion of Living Conditions Studies, Bureau of Labor Statistics, June 1968.

95. There is some temptation to have the Bureau of Labor Statistics set the supple. ment levels itself, based on its annual family budget studies, in the form of tables for different types of family units in various living situations. This would not only leave the determination of basic supplement guarantees-one of the most important elements of the statute-to an administrative agency, but would also prevent Congress from passing on the cost of the program until the time came for appropriating funds. 
ments paid to family units residing within its jurisdiction. The amount of the increase shall be set by the legislature of the electing state, but supplement levels for all family units within the state must be increased by the same proportion. Except as otherwise provided in this Act, any such increase under this section shall apply without exception or condition to all family units for such time as they reside within the jurisdiction of the electing state.

(b) Residency.-For the purposes of this section, a family unit shall be deemed to reside within a state for the period, if fifteen or more days consecutively, that the claimant or claimants regularly occupy a dwelling unit within such state. Where the claimants in a twoclaimant family unit occupy separate dwelling units for any period of time, the family unit shall be deemed to reside for such period in the dwelling unit which the members occupy more frequently.

(c) State Sharing of Additional Costs.-A state electing to increase income supplements for its residents under this section shall pay each year one-half the cost of such increase into the federal Treasury, at a time and in a manner designated by the Secretary. An electing state shall have access to information adequate to determine its liability under this section.

(d) Period of Election.-An election by a state under this section shall be effective sixty days after the Secretary has received formal notice of the election, or at such later date as the notice shall specify, and until the state revokes, terminates, or modifies it, by appropriate legislation and notice.

(e) Other Sections Applicable.-Except as explicitly provided in this section, the income maintenance program provided for in this Act shall operate in electing states exactly as it operates in nonelecting states. By election of increased benefits under this section, a state shall not increase its involvement in the administration of this Act in any way whatsoever. The rights of members of a family unit under other sections of this Act shall not be diminished or abridged in any way by the provisions of this section.

\section{Comment}

Section 6 allows a state to set a higher supplement level for its residents, but only if it bears one-half the additional cost. The state's election only changes the amount of the family income supplements under section 5; in all other respects the rules and administration of the NIT remain exactly as 
in non-electing states. Except for paying its annual bill at the federal trea. sury, the state plays no further part in the program.

In particular, the section makes clear that an electing state can impose no restrictions on the distribution of the additional supplements. All participating family units who have lived in the electing state for fifteen days must receive the extra payment, and all in the same proportion to the regular income supplements paid them for the time they are in the state. The fifteen-day period is technically a durational residency requirement, but keeping track of smaller periods of time would be too great an admin. istrative burden on either the government or the recipients themselves. 00 Even if the family fails to meet the requirement, it still receives the basic national supplement; only the electing state's addition is lost. Moreover, a family who meets the requirement will get the additional supplement for the first fifteen days as well as for the rest of its residency in the state, and the period is so short that even migrant families should not suffer from it. Thus, subsection (b) does not seem to pose the kinds of constitutional problems present in the residency requirements of current state welfare programs.

\section{Section 7. Special Tax}

There is hereby imposed on every electing family unit a special tax equal to 50 per cent of the family unit's available income during its supplement period; provided, that in no case shall the special tax imposed on a family unit exceed the amount of the income supplement to which it is entitled for the same supplement period under sections 5 and 6 of this Act.

\section{Comment}

Section 7 sets up the mechanism through which a family unit's basic annual supplement is reduced as the family unit's available income, defined in sections 10 and 11 , increases. This so-called "tax" can never result in a positive transfer to the government, since it can never exceed the amount of the supplement to which the family unit is entitled under sections 5 and 6. The operation of the tax and some of the policy considerations involved in setting the rate have already been discussed in the Introduction.

96. Recent federal district court decisions have held prolonged residency requirements, typically a year, invalid either for violating the equal protection clause or as imposing an unconstitutional restriction on interstate travel or both. E.g., Thompson v. Shapiro, 270 F. Supp. 231 (D. Conn. 1967), prob. juris. noted, 389 U.S. 1032 (1968)! Smith v. Rcynolds, 277 F. Supp. 65 (E.D. Pa. 1967), prob. juris. noted, 390 U.S. 920 (1968) (one year requirc. ment); Green v. Dep't of Pub. Welfare, 270 F. Supp. 173 (D. Del. 1967); Harrell v. To. briner, 279 F. Supp. 22 (D.D.C. 1967) (one year). 
Section $11(c)(8)$ shows the precise relationship between the special tax of Section 7 and the positive income tax of the Internal Revenue Code. Roughly speaking, the special tax is 50 per cent of income as comprehensively defined under this Act, minus any positive tax on that income. Thus the sum of a family unit's tax "obligations" under both taxes never exceeds 50 per cent of income.

\section{Section 8. Annual and Semimonthly Payments}

(a) Final Returns.--Every family unit electing to receive an income supplement under this Act shall file a return at the local or district office of the Bureau of Income Maintenance, either by mail or in person, on or before the fifteenth day of the fourth month following the close of the supplement period for which the return is made. The return shall be signed by all claimants in the family unit and shall contain sufficient information for an accurate appraisal of the family unit's rights and obligations under this Act.

(b) Annual Payments and Settlements; Liability.-Within 30 days of receipt of a final return, the Secretary or his delegate shall provide payment of the income supplement due the family unit under this Act; provided, that if the family unit elected to receive semimonthly payments under subsection (c) during the supplement period to which the final return required by subsection (a) applies, the Secretary or his delegate shall make a final determination of the family unit's rights and obligations under this Act and shall (i) direct payment of any amount due the family unit or (ii) notify the family unit of its liability for any payments received to which it was not entitled. All claimants in the family unit shall be liable -both jointly and severally-for any payments received under this Act to which the family unit was not entitled.

(c) Right to Semimonthly Payments.-A family unit shall be entitled to receive its income supplement in semimonthly payments. A request to receive semimonthly payments shall constitute an election under section 3 of this Act for one full supplement period.

(d) Manner and Time of Request.-A family unit may request to receive semimonthly payments of its income supplement at any time. The request shall be made in writing, signed by all claimants in the family unit, and filed at the local or district office of the Bureau of Income Maintenance, either by mail or in person. Such a request shall be accompanied by an estimate of quarterly available income as provided in subsection (i)(1). The Secretary shall approve and 
implement such a request on the first payment day, as specified in subsection (e), after the request is filed with the Bureau, unless the claimants knowingly request in writing that the semimonthly payments begin at a later date, in which case the Secretary shall begin payments on the requested date; provided, that if the requested date is not a payment day as provided in subsection (e), the Secretary shall begin payments on the first payment day preceding the requested date.

(e) Timing and Amount of Payments.-Family units requesting semimonthly payments under this subsection (c) shall receive on the first day and on the fifteenth day of each month during the supplement period for which the request is effective an amount equal to one twenty-fourth of the amount to which the family unit would be entitled for a full calendar year under sections 5 and 6 , less any amounts deducted as provided in subsections (i) and (j) of this section. For the purposes of this subsection, the amount of the annual supplement shall be determined initially by the family unit's composition and residence, as reported in the request for semimonthly payments. The Secretary shall determine the amount of the semimonthly payments on the basis of the facts as stated in the family unit's request, accompanying income statement, and subsequent quarterly estimates under subsection (i)(1). The Secretary shall adjust the amount of the annual supplement as required by changes in family composition within 30 days after notification under subsections ( $\mathrm{f}$ ) and (g).

(f) Change in Family Status.-A family unit receiving semimonthly payments under subsection (c) shall notify the Bureau of Income Maintenance, through its local or district office, of any change in the family unit's dependents within 30 days of its occurence.

(g) Notice of Change of Residence.-A family unit receiving semimonthly payments under subsection (c) shall notify the Bureau of Income Maintenance, through a local or district office, of any change of residence within 15 days after the change has occurred.

(h) Termination or Reduction of Semimonthly Payments.-

(1) By the family unit.-The claimant, or either claimant in a family unit with two claimants, may terminate semimonthly payments to the family unit at any time by filing a written request for termination at an office of the Bureau of Income Maintenance. A termination under this subsection shall not affect the right of the family unit to request semimonthly pay- 
ments at any subsequent time. Termination of semimonthly payments shall not revoke or terminate the election of the family unit under section 3 of this Act, or any of the requirements or duties imposed by a section 3 election.

(2) By the Secretary.-If the Secretary determines that a family unit's income supplement should be terminated or reduced, he shall not discontinue or reduce semimonthly payments to the family unit until the family unit has had an opportunity for a hearing and an appeal, as provided in section 19 of this Act. If the family unit seeks review of the Secretary's decision in a federal district court, the court may further stay the discontinuance or reduction of semimonthly payments.

(3) At the Close of the Supplement Period.-Semimonthly payments to a family unit shall terminate at the close of the family unit's supplement period, as determined by section 4 of this Act, unless the family unit files a request as provided in subsection (d) in respect to the new supplement period.

(i) Deduction of Tax on Estimated Available Income.-

(1) Quarterly Estimates of Available Income Required.-A family unit which requests and receives semimonthly payments under subsection (c) shall, at the time of filing such request and at the end of each succeeding quarter so long as the family unit continues to receive semimonthly payments, file an estimate of the amount of the family unit's available income for the year of election, including such amounts as would be included under sections 12 and 13 of this Act. Subject to the provisions of subsection (i)(2), this estimate shall be an extrapolation based on an estimate of the amount of the family unit's available income during the last preceding quarter year, or during those quarters of the year of election which precede the date of the estimate, whichever period is longer.

(2) Fluctuating incomes.-In filing the estimate required by subsection (i)(I), the claimant or claimants shall state if there is reason to believe that the family unit's available income for the year of election will differ from the estimate as calculated according to subsection (i)(1) by 10 per cent or more, the ground for such belief, and the probable amount of the increase or decrease. In such a case, the Secretary shall increase or decrease the estimate of available income by the declared amount for the purposes of calculating the tax under subsection (i)(3). 
(3) Deduction of tax.-The Secretary shall deduct and withhold ratably from each semimonthly payment a tax computed according to section 7 of this Act, and based upon the estimated available income for the year of election, determined as provided in this subsection. The amount deducted and withheld shall be allowed as a credit when the annual settlement is made under subsection (b).

(j) Deductions for Underpayments.-The amount of any underpayment attributable to an earlier period, or determined by a final accounting either of the special tax imposed by section 7 of the Act or of the income tax imposed by the Internal Revenue Code of 1954, for which the family unit or any members thereof are liable, may be deducted from any semimonthly payment, but no deduction under this subsection shall exceed 0.5 per cent of the amount to which the family unit is entitled under sections 5 and 6 . The amount of the deduction shall be allowed as a credit against any underpayments.

(k) Supplement Checks.-Except when a claimant shows that an alternative form of payment is appropriate, supplement checkswhether annual or semimonthly-shall be made out jointly to all claimants in a family unit.

\section{Comment}

Under section 8 each family unit may choose to receive current semimonthly payments of its NIT benefits rather than receive a lump-sum payment at the end of the year. As with the positive tax and its year-long withholding provisions, the annual return would then become a final settling-up occasion, possibly with only small sums involved. A decision to receive semimonthly payments requires the family to remain under the program for an entire supplement period even though it may stop the payments at any time. Once a family has received NIT benefits, it must file a return at the end of the supplement period and settle its accounts with the government on the basis of the entire supplement period.

Since the claimants of the family unit are liable for all monies received and for the final accounting to the Government, all claimants in a unit must request semimonthly payments, and any claimant can terminate the payments to a family unit at any time. Families which decide to receive NIT benefits currently are likely to be quite poor; the statute, therefore, requires the Secretary of the Treasury or his delegate to begin the payments almost immediately. Even if the Secretary thinks the amount claimed is too high or finds the application in any way defective, he may 
not refuse or reduce payments without first providing the recipients an opportunity for a hearing with the procedural protections provided by section 19.

The amount of the semimonthly payments varies according to the special tax obligations, thus assuring that they are in line with the families' need for additional income. Therefore all NIT recipients who receive semimonthly payments must file quarterly estimates of annual income, and the Secretary shall deduct from each semimonthly payment one twenty-fourth of the 50 per cent "tax" on estimated annual income. By deducting the estimated tax from the income supplement payments and not withholding it from wages, the government pays out less money and the recipient receives more of his total income from employers. If a withholding system were used, the government would pay out large sums with one hand while taking back much of the money with the other. Secondly, the administrative expense of a second withholding system would burden employers and employees as well as the government. Finally, the lower visibility of the estimation system advances the goal of social integration. ${ }^{97}$

Where there are two claimants in a family unit, section 8 requires that supplement checks be made out jointly to both. This procedure prevents either claimant from cashing the check without the explicit consent of the other, and also encourages claimants to inform the Bureau of Income Maintenance whenever one of them leaves the family unit.os To prevent undue hardship or inconvenience, the Secretary may permit another form of payment in special cases, such as when the claimants are separated geographically or one is incapacitated.

\section{Section 9. Family Unit Defined}

(a) General Rule.-A family unit shall consist of at least one claimant, and not more than two claimants, and any dependents which the claimant or claimants, individually or jointly, are entitled to claim and which all the claimants in a family unit choose to claim, except that any person 16 years old or older who is claimed as a dependent must agree in writing to be claimed as a dependent.

(b) Claimants.-Any person who-

(1) is 21 years of age or older, or

(2) is 19 or 20 years of age and maintains a domicile separate from

97. A withholding system poses particular problems for an NIT program using family units as its base. A parent could subject a dependent's income to the withholding tax without the consent of the dependent. Where the dependent had refused to share any of his income, the withholding system would encourage the parent to claim the dependent and thereby get the government to act as the parent's collection agency.

98. See Income Maintenance Hearings 188. 
his parents or guardian, does not receive more than half his support from his parents or guardian, and is not a student within the meaning of section 151(e)(4) of the Internal Revenue Code of 1954, or

(3) is under 21 years of age and is married, provided that he and his spouse maintain a common domicile, are not legally separated under a decree of divorce or of separate maintenance, or informally separated, as defined by subsection (e),

may declare himself a claimant under this provision of this Act for so long as he resides in the United States or its territories.

(c) Dependent.-A claimant or claimants in a family unit may declare as a dependent under the provisions of this Act any person who-

(1) is a son or daughter of the claimant, or is any person for whom the claimant is legal guardian, provided that such person, son, or daughter receives a significant portion of his support from the family unit of the claimant, or is a student within the meaning of section 151(e)(4) of the Internal Revenue Code of 1954, or

(2) is any other person who receives over half of his support from the family unit of the claimant and who resides in the same dwelling unit as the claimant,

provided that such person has not rightfully declared himself a claimant under subsection (b), or has not been rightfully declared as a dependent under this subsection by a claimant in another unit which in fact provided the larger share of the declared dependent's support during the preceding twelve months. The Secretary or his delegate may require any claimant who declares a person as a dependent under subsection (c)(2) to substantiate the amount of support provided the dependent and the residence of the dependent.

(d) Required Family Units.-

(1) A husband and wife, who have not been informally separated, legally separated or divorced, must file as members of the same family unit.

(2) A man and a woman, domiciled together and the common parents of at least one child, must file as members of the same family unit.

(e) Informal Separation Defined.-A husband and wife shall be considered informally separated for the purposes of this Act if- 
(1) they have not lived in the same dwelling unit for 30 consecutive days, and

(2) they do not maintain a common residence, and

(3) one of the spouses files an affadavit with the Secretary, swearing or affirming these facts on information or belief and further stating a belief that the separation will continue indefinitely.

(f) Special Rule for Required Family Units.-

(1) Notwithstanding the provisions of subsection (a), a claimant in a family unit required to file together under subsection (d) shall be entitled to receive, in respect to any dependent of such claimant-

(A) who is orved no duty of support by the other claimant in the family unit, and

(B) whom such other claimant refuses to support,an income supplement as provided by section 5 of this Act, not reduced in amount by reason of the special tax imposed by section 7 of this Act on income attributable solely to such other claimant; provided, that the family unit shall receive no other income supplements in respect to such dependent. Any income supplement paid to both claimants jointly shall be determined by treating the family exclusive of such dependent as a separate family unit for the purposes of sections 5 and 7 of this Act.

(2) The supplements provided under this subsection for the benefit of dependents specified in paragraph (l) shall be reduced by 50 per cent of (i) any support actually provided by the refusing claimant and (ii) any income earned by the non-refusing claimant and such dependent; provided, that the family unit including such dependent shall not receive benefits less than it would be entitled to if this subsection did not apply.

(3) The Secretary or his delegate, before making any payments under this subsection, may require from the claimant refusing support an affidavit attesting that (i) he is under no legal obligation to support such dependent and (ii) he will not adequately support such dependent during the supplement period involved. The law of the state in which the family unit resides shall determine to which dependents the refusing claimant owes an obligation of support.

(g) Limitations on Family Units.-No person shall be declared as a claimant or dependent of more than one family unit during the same period of time. 


\section{Comment}

The policies underlying the choice of the family unit to determine the amount of NIT benefits have been discussed in the Introduction. ${ }^{90}$

Section 9 declares that persons are eligible to receive NIT benefits only while they live in the United States or its territories. The program excludes Americans living abroad primarily to avoid the possibility that a lower cost of living in other countries would attract many recipients and produce a serious outflow of United States funds.

This section also restricts those people who are permitted to claim benefits as heads of a family unit to persons over 21, married minors, and 19- or 20-year-olds who have left their parents' home and no longer receive support from their parents. The latter two categories recognize a social policy favoring independence among young people, ${ }^{100}$ but to avoid wholesale subsidization of middle-class college students the exception made in behalf of inclependent 19- or 20-year-olds applies only to those not in school. A claimant may name as dependents any of his children or legal wards if they are sup. ported by the claimant, live with him, or are full-time students. Living arrangements among the poor are often informal, however, and adults sometimes support and care for minors who are only distant relatives, or no relation at all.101 To cover such cases, the statute permits a claimant to declare anyone whom the claimant in fact supports and who lives with the claimant as a dependent. Slightly higher standards of proof might be required of a claimant before such a dependent is allowed.

The only groups of people clearly left out by the statute are orphans (some negative income tax plans have proposed a special exception for them ${ }^{102}$ ) and emancipated minors under 19 years of age.

\section{Section 10. Computation of Available Income of the Family Unit}

The available income of the family unit for any period shall be the sum of the available incomes of all its members during such part of that period as they are claimed as members of the family unit for the purposes of section 5 of this Act; provided, that no item of income shall be included, nor any deduction allowed, more than once.

99. See pp. 276-81 supra.

100. See Tobin, Pechman \& Mieszkowski, supra note 6 , at 11.

101. Gibbard, Poverty and Social Organization, in Poverty AND Afrluence 45, 51 ( $L$. Fishman ed. 1966).

102. This provision was suggested in an unpublished paper developed by the Institute for Research on Poverty at the University of Wisconsin in setting up the New Jersey NIT experiment for OEO (copy on file at the Yale Lav Journal). See note 19 supra. 
Section 11. Determination of Available Income of Persons

(a) In General.-For the purposes of this Act, a person's available income shall be his adjusted gross income, as defined in section 62 of the Internal Revenue Code of 1954, with the modifications provided by subsections (b)-(h).

(b) Amounts Added to Adjusted Gross Income.-For the purposes of subsection (a), adjusted gross income for any period shall include the amount of the following items which accrue or are received during such period to the extent they are not already included in the definition of adjusted gross income in section 62 of the Internal Revenue Code of 1954:

(1) The entire amount of any payments received as an annuity, pension, or retirement benefit,

(2) The amount or value of any and all prizes and awards,

(3) The proceeds of any life insurance policy in excess of the premiums paid personally by the beneficiary or the beneficiary's spouse,

(4) All gifts (cash or otherwise), support and alimony payments, and inheritances, in excess of a total of $\$ 50$ per year, except for any gift or support payment or other transfer received from a member of the same family unit or from a private charity, and except for any property inherited from a deceased spouse,

(5) Interest on all governmental obligations,

(6) Except as otherwise provided in this Act, any amount received in the form of damages, insurance payments, workmen's compensation, or in any other form as (i) compensation for physical, mental or any other personal injuries or sickness, (ii) wage or income continuation payments, or (iii) payments for medical expenses,

(7) The rental value of parsonages,

(8) Certain combat pay and mustering-out payments to members of the Armed Forces excluded from adjusted gross income by sections 112-13 of the Internal Revenue Code of 1954,

(9) The full amount of all dividends,

(10) The full amount of any scholarship or fellowship,

(11) The amount by which living expenses of the family unit are reduced when an employer supplies meals or lodging at less than their fair market value, regardless of whether the arrangement was made for the convenience of the employer, 
(12) Any amount paid by the government to a member of the Armed Forces as an allowance for quarters or subsistence or as gratuity pay,

(13) The amount of current or accumulated income that could, within the discretion of any person with a nonadverse interest, be paid to an individual from a trust or estate of which he is a designated beneficiary, except that any such amount not exceeding $\$ 3,000$ and in fact paid to some other person shall not be so included,

(14) All amounts deductible under section 1202 of the Internal Revenue Code of 1954,

(15) All unemployment compensation, from whatever source derived, whether from government insurance programs or otherwise, but excluding payments made pursuant to section 407 of Title IV of the Social Security Act,

(16) Strike benefits received from any union or other organization or agency,

(17) All cash benefits received pursuant to Title II and XVIII of the Social Security Act, but excluding (i) all payments made pursuant to Titles, I, IV, XIV, XVI, and XIX of the Social Security Act and (ii) all sums received under any government program where the financial need of the recipient is an essential prerequisite of the award,

(18) Railroad Retirement Act cash benefits,

(19) Cash benefits under laws administered by the Veterans' Administration,

(20) Foreign source income presently excludable under sections 893, 894, 911, 912, 931, and 943 of the Internal Revenue Code of 1954 .

(21) Amounts received as loans from the Commodity Credit Corporation,

(22) Items presently deductible under sections 173, 175, 180, 182 263(c), 615, and 616 of the Internal Revenue Code of 1954,

(23) Imputed income, as defined in section 12 of this Act, and

(24) Capital utilization income, as defined in section 13 of this Act.

(c) Deductions Allowed.-For the purposes of subsection (a), adjusted gross income for any period may be reduced by the amount of the following items which accrue, are paid, or are otherwise deductible during such period, to the extent that they have not already been deducted from adjusted gross income under the provisions of the Internal Revenue Code of 1954: 
(1) All expenses for medical care within the meaning of section 213(e) of the Internal Revenue Code of 1954, except that-

(A) this deduction shall not apply to expenses compensated for by insurance or otherwise, where such compensation has been excluded from available income, and

(B) deductions can be made under this section only to the extent that the aggregated medical expenses of the family unit during the period involved exceed \$25 for each person-,

(2) Alimony, separate maintenance, and support payments required by law and actually made by the taxpayer,

(3) The value of any gift to a member of a family unit other than the donor's where the donee is a member of a family unit receiving payments under this Act, but only if the donor can present a signed statement from the donee attesting to such transfer,

(4) All deductions presently allowable under sections 162 and 212 of the Internal Revenue Code of 1954, provided, that the cost, in excess of $\$ 10$ per month, of all transportation to and from work may be deducted,

(5) Any deduction allowable under section 214 of the Internal Revenue Code of 1954, except that for purposes of this Act "dependent" in section 214(d)(1) shall be defined by section 9(c) of this Act,

(6) All amounts deductible under section 404 of the Internal Revenue Code of 1954,

(7) An amount equal to twice the taxes imposed by subtitle $A$ of the Internal Revenue Code of 1954 on the taxable income of any member of the family and paid during the period involved, including any amounts paid pursuant to Chapter 24 of the Internal Revenue Code of 1954 as withholding taxes, less twice the amount of any credits allowed against such taxes by sections 33 to 40 of the Internal Revenue Code of 1954, provided, that the maximum deduction allowable to a family unit under this section shall not exceed the income supplement to which the family unit is entitled under section 5 of this Act, and

(8) Employee contributions under the Social Security and Railroad Retirement Acts.

(d) In determining adjusted gross income for the purpose of subsection 
(a), losses may be deducted to the extent allowable by sections 165 and 172 of the Internal Revenue Code of 1954, except that-

(1) no deduction shall be allowed for losses described in $\S 165(\mathrm{c})(3)$ of the Internal Revenue Code of 1954 (casualty losses),

(2) deductions for losses from sales or exchanges of capital assets shall be allowed only to the extent of gains from such sales or exchanges, and no deduction for capital losses shall be allowed unless realized in a period during which the individual was a member of a family unit entitled to receive an income supplement in excess of its special tax liability under this Act without the benefit of this deduction,

(3) for the purposes of this Act, the term "net operating loss" as used in section 172 of the Internal Revenue Code of 1954 shall mean the excess of the deductions allowed by this Act over the income obtained by the operation of section 11(b) on adjusted gross income, although such excess shall be computed with the modifications specified in section $172(\mathrm{~d})$ of the Internal Revenue Code of 1954,

(4) no carryover or carryback of any net operating loss shall be allowed unless the loss occurred in a period during which the individual was a member of a family unit receiving an income supplement in excess of its special tax liability under this Act, and

(5) no loss may be deducted under this Act which has been deducted under the provisions of the Internal Revenue Code in any period during which the individual was not a member of a family unit receiving an income supplement in excess of its special tax liability under this Act.

(e) Depreciation and Depletion.-In determining available income, a deduction shall be allowed for depreciation and depletion only to the extent permitted by sections 167 and 611 of the Internal Revenue Code of 1954; but no deduction shall be permitted for depletion calculated pursuant to section 613 of the Internal Revenue Code of 1954.

(f) Deductions Disallowed.-Deductions from income other than those specifically allowed in this section are disallowed. No item shall be deducted more than once.

(g) Subchapter S Corporations.-Any amount attributed to the available income of a member of the family unit by operation of section 1373 of the Internal Revenue Code of 1954 shall be increased by an amount proportional to the amount by which the taxable income 
of the electing corporation would be increased if computed under this section.

(h) Internal Revenue Code Applicable.-Except where this Act provides or necessarily implies otherwise, the provisions of the Internal Revenue Code of 1954 shall apply in the determination of available income.

\section{Comment}

Sections 10 and 11 define the family unit's "available income" subject to the special tax imposed by section 7. Available income, as defined in these provisions, is an attempt to measure all the resources of the family unit available for consumption. ${ }^{103}$ Unfortunately, adjusted gross income (AGI), the principal income concept of the Internal Revenue Code, does not adequately measure these resources. ${ }^{104}$ The Code provisions reflect a far greater variety of economic and social policies than those relevant to the NIT, and adjusted gross income thus differs substantially from strictly economic concepts of income. If the deviation of AGI from economic income were uniform, simplicity would favor using AGI in spite of its defects. Since AGI is inconsistent even in its flaws, the use of AGI would permit claims by persons whose economic incomes are high though they show low adjusted gross incomes. ${ }^{105}$ The number of such persons who might qualify for aid would undoubtedly be small, but their presence would be a strong political liability for any program. Consequently, while AGI has been used as a base, considerable adjustment was necessary. It is important to note that the complexities introduced do not, except for the inclusion of certain transfers and government subsidies, affect most of the eligible recipients, and so should not become a significant burden for most of the electing families.

Most of the major alterations, except for the capital consumption feature, follow the Haig-Simons concept of income: "the increase or accretion in one's power to satisfy his wants in a given period in so far as that power consists of (a) money itself, or (b) anything susceptible of valuation in terms

103. For a favorable discussion of the aggregation of income for family units in a positive tax system, see 3 Royal CoMarssion on TAXition, Report 122-51 (1960) (Canada). But see Bittker, Income Tax Reform in Canada: The Report of the Rojal Commission, 35 U. CHI. L. REv. 637, 645-50 (1968) ("Aggregation] fails to talie sufficient account of the independence, in today's social milieu, of adolescent youth.").

104. In 1960 the difference between AGI and personal income, as defined in the national income accounts, was $\$ 52$ billion. $R$ Goode, THE INDIviduAL INcome TNx 6 (1964). For general discussion of the need to develop a special definition of income for the NIT, see G. Green, supra note 5, at 82-99; Tobin, Pechman \& Mliesliowsli, supra note 6 , at 11-20; Income Maintenance Hearings 95, 100. The effect of various provisions in the Internal Revenue Code on the distribution of the positive tax burden among income classes is tabulated in B. ORNER, INCOME DISTRIBUtion AND THE FEDERAL INCOME TAX 75 (1966).

105. See P. Stern, The Great Treasury Ram 3-16 (1964). 
of money." 106 Although resort to this criterion solves many problems in the definition of available income, there are areas upon which it sheds little light $\mathrm{t}^{107}$ and which require that other principles be brought into play. For instance, the designation of the family unit and the treatment of alimony and support payments depend upon independent notions of what are appropriate consumption and taxation units, and in no sense derive from the adoption of the Haig-Simons concept.

Even where the implications of the Haig-Simons definition are clear there have been some departures. First, the administrative difficulties of valuing certain accrued benefits and gains have often required the use of less principled but more practical methods. Especially in matters of timing and distinguishing business from private expenses, ${ }^{108}$ the statute has frequently adopted current Code procedures despite the resulting deviations from a more ideal definition. Second, the minimum needs of some family units differ substantially from those of the general population, and it is simpler -if less precise-to provide for these families by allowing them deductions from available income rather than by increasing their income supplement. ${ }^{109}$

With a few exceptions, available income includes all income from labor and capital-actual and imputed, government and private transfer payments, home-grown food, and other income-in-kind. The statute also assumes that families can use a certain portion of their wealth for consumption and therefore counts a substantial portion of a unit's net worth, above a certain level, as available income.

The most important additions section 11 makes to adjusted gross income as defined in the Internal Revenue Code are private and government trans. fers, pensions and annuity payments, and imputed income. Private transfers

106. Haig, The Concept of Income-Economic and Legal Aspects in THE FEDERAL IN. COME TAX 7-28 (R. Haig ed. 1921). A definition thought to be equivalent is offered by Simons: "[T] he algebraic sum of (I) the market value of rights exercised in consumption and (2) the change in the value of the store of property rights between the beginning and end of the period in question." H. Simons, PERSONAL INCOME TAXATion 50 (1938).

The implications of these definitions and their limitations in resolving many practical problems of taxation have been carefully explored by Professor Bittker in $A$ "Comprehen. sive Tax Base" as a Goal of Income Tax Reform, 80 HARV. L. REv. 925 (1967). For positions more favorable to the Haig-Simons definition, see Musgrave, In Defense of an In. come Concept, 81 Harv. L. REv. 44 (1967); Pechman, Comprehensive Income Taxation: A Comment, 81 Harv. L. Rev. 63 (1967); Galvin, More on Boris Bittker and the Com. prehensive Tax Base: The Practicalities of Tax Reform and the ABA's CSTR, 81 HARv. $L$. REv. 1016 (1968). But see Bittker, Comprehensive Income Taxation: A Response, 81 Hanv. L. REv. 1032 (1968).

107. See generally Bittker, Comprehensive Tax Base, supra note 106.

108. See Bitter, Comprehensive Tax Base, supra note 106, at 952-73.

109. A deduction is equivalent to an increase in the supplement of 50 per cent of the expenditure if the family has other available income against which the deduction may be applied. The deduction provides proportionally less relief to families whose available income is less than the amount of the deduction. 
here mean not only gifts and inheritances, but also benefits under health and accident plans and some life insurance benefits. ${ }^{110}$

Since the concern of the statute is to guarantee everyone the means to attain a minimum level of consumption, transfers are included in the recipient's income and excluded from the transferor's. To discourage voluntary transfers from low-income families to higher income groups, however, gifts to families who do not receive net benefits under the program are not deductible. Because the special tax rate is the same for all families, deductions for transfers between electing family units which receive net benefits from the NIT impose no extra cost on the program.

Assistance by private charity poses a knottier problem. To include such transfers in the available income of the recipient would mean that he would receive half the amount of the private aid. The result might be to discourage such assistance. ${ }^{111}$ On the other hand excluding the payments would mean that families receiving private relief would get the same NIT benefits as less favored groups. On the assumption that private relief goes chiefly to families whose needs are sharply differentiated from the general public, such as disaster victims or persons with extraordinary medical expenses, charitable transfers are not included in available income. Experience may demonstrate that finer distinctions are necessary.

A special aspect of the transfer problem is the treatment of benefits in trust. In general, available income should include only completed gifts, 112 but in order to prevent obvious abuses current or accumulated income in a trust or estate which could be distributed to an electing individual is also included in available income unless payment is within the discretion of someone with an adverse interest or, to the extent of $\$ 3000$, the income in fact goes to some other party. ${ }^{113}$

Government transfer payments ${ }^{114}$ pose a range of similar questions. Because of the major problems of valuation and allocation, non-cash and indirect benefits are not considered within available income. As for benefits which can be readily allocated and valued, several approaches are possible.

110. The arguments favoring taxation of these items in the positive tax sjstem are reviewed by $R$. GOODE, supra note 104, at 99-151, 184-221.

111. The impact of taxation upon charitable giving is far from clear. Tax incentives apparently have little effect upon donors subject to tax rates of 20 to 30 per cent. C. KafN, Personal Deductions IN THE Federal Income Tax 72 (1960). Experience with the positive tax system applied to individuals is not much of a guide to the effects of a 50 per cent tax on limited activities of otherwise tax exempt organizations.

112. Regulations will have to be adopted to determine when a gift is complete. In this respect the gift tax, the estate tax, and the income tax are not always consistent. See Commissioner v. Beck's Estate, 129 F.2d 243, 246 (2d Cir. 1942). See generally cases and notes in B. BITTKER, FEDERAL INCOME, ESTATE AND GIFT TAXATION $1007-20$ (1904).

113. This provision was suggested in an unpublished working paper developed by the Institute for Research on Poverty at the University of Wisconsin in setting up the New Jersey NIT experiment for OEO (copy on file at the Yale Law Journal).

114. See Bittker, Comprehensive Tax Base, supra note 106, at 995-38. 
If NIT supplements are high enough to provide an adequate minimum in. come, available income should include full benefits from other programs, except for those providing assistance to persons, such as the handicapped or blind, whose needs are sharply different from and greater than the needs of the rest of the population. If the NIT supplement level is less than the currently defined poverty levels, however, it seems desirable to exclucle from available income any special assistance payment geared to financial need. This exclusion would ensure that assistance programs adjust their payments to the NIT supplements, making a second correction by the NIT unnecessary. This is the approach that the statute has adopted. Section 11(b) lists the principal types of payments excluded by this criterion, ${ }^{115}$ but the administrators of the program must determine what other federal and state programs include adequate means tests to qualify for exemption. ${ }^{116}$ Government transfers not tied directly to financial need are within available income; among the more important of these are farm subsidies, ${ }^{117}$ veterans' benefits, ${ }^{118}$ and retirement and income maintenance payments. ${ }^{110}$

Pensions and annuities are fully included even though they involve some element of capital return.120 To compensate, the capital utilization section ${ }^{121}$ excludes pension and annuity rights from basis. This procedure simplifies the calculation involved and probably reflects more accurately the individual's own perception of his income. In equal part for consistency and for administrative simplicity, employer contributions to qualified pension funds are not included in available income. ${ }^{122}$

One small, but troublesome point is the inclusion of scholarship aid (including any portion for tuition). Undeniably, family units with members receiving higher education at a discount enjoy a valuable benefit. Yet it is not a benefit readily convertible into other goods and services. The dilemma is not so great as it seems, however, because a family unit can avoid paying the special tax on a scholarship simply by not claiming the member who receives it as a dependent. Since that member would often not depend on the family for his support, anyway, this result seems acceptable.

Section 11 allows those deductions necessary to obtain an accurate measure of a family unit's consumption resources. In general, this criterion permits

115. Income Supplement Act \& 11(b)(17).

116. As of 1967 there were 459 separate domestic assistance programs opcrated or funded by the federal government, and a sizable number of these provide direct financial assistance. See OfFice of Economic OpPortunity, Catalogue of Federal AssistancE: PrOGRAMS (1967). In addition, rulings will have to be issued for various state prograuls.

117. Income Supplement Act \& 11 (b)(21). In effect this makes the elcction of section 77 of the Internal Revenue Code of 1954 mandatory for purposes of the NIT.

118. Income Supplement Act \& 11(b)(19).

119. Id. \$§ 11(b)(6), $1 \mathrm{l}(\mathrm{b})(15)-(18)$.

120. Id. § $11(\mathrm{~b})(\mathrm{l})$.

121. Id. § 12(c), 13(b).

122. This procedure follows that of the Code. See INT. REv. CODE of 1954, $\$ 4401.05$. The major issues concerning taxation of these items are discussed in R. GoodE, supra note 104 , at 102-17. 
deductions only for expenses incurred in the production of income and for certain nondiscretionary expenditures that take precedence over ordinary consumption. The most important are the "business expense" deductions, which the statute borrows wholesale from sections 162 and 212 of the Code. ${ }^{123}$ The statute also adopts the child care deduction of the Code 124 since a large percentage of poor families have only one adult member, ${ }^{125}$ and for them child day-care is an unavoidable cost of earning a living. Section 11 departs from the Code in allowing a deduction for commuting expenses above $\$ 10$ a month. Since low-income families have a limited choice as to where they reside, it seems more realistic to treat such travel as a business, rather than a consumption, expense.125/2

In deducting from income the expenses of producing it, deductions for operating losses, capital losses, depreciation and depletion are necessary, but difficult to allocate to the proper time period. Ideally, changes in value would be recorded annually, and only those losses and declines in value accruing during the relevant period would be deductible. Since this is not administratively feasible, the statute accepts the Code rules, with a few modifications. To keep depreciation and depletion deductions closer to reality, section 11 does not allow accelerated depreciation (except as permitted in section 167), percentage depletion, or the additional small business depreciation allowance.

Under the Code, it is possible to deduct losses which accrued during other periods, and the statute introduces several restrictions to control, rather imperfectly, abuses which this feature might encourage. Subsection 11(d) limits deductions for capital losses to the amount of capital gains, permits carryovers only of losses realized during periods when the family unit received net NIT benefits, and-to prevent double use of a loss-allows no carryover if the taxpayer has deducted the amount in determining his income tax for a no-net-benefit period. ${ }^{120}$ Finally, the statute modifies the definition of operating loss slightly to conform with the definition of available income.

123. There are, of course, a number of problems in defining "business expenses." See Bittker, Comprehensive Tax Base, supra note 106, at 952-54.

124. INT. REv. CODE OF 1954, § 214.

125. See Orshansky, Who's Who Among The Poor, supra note 87, at 3. Forty per cent of poor families have only one adult member compared to 14 per cent for the remainder of the population. See Orshansky, The Shape of Poterly in 1966, supra note 4, tables $5 \& 6$.

125a. Some of the special locational problems of the poor are analyzed in Kain. Housing Segregation, Negro Employment and Netropolitan Decentralization, 82 Q.J. EcoN. 175 (1968).

126. A similar limitation is already imposed by INT. REv. Cone of 1954, $\$ 1211(\mathrm{~b})$. Its rationale, based on the different rates on long term capital gains and other incomc, how: ever, applies only in the indirect sense that different rates exist if losses are taken in years when $a$ benefit is obtained and gains are taken in years in which the family is ineligible for supplements.

Operating losses which are less likely to have accrued over several years are treated more generously and may be deducted as in the Code to the full extent of the current jear's income. But see Income Supplement Act \$ II(d)(l) (casualty losses not deductible). 
Casualty losses unrelated to the production of income are not deductible under the statute. ${ }^{127}$ While these losses can substantially increase a family's need, the statute generally avoids provisions for special cases and instead relies on other government programs to meet abnormal or emergency needs. The major deviation from this principle are the deductions allowed for extraordinary medical expenses. Unlike other non-discretionary expenditures, special medical expenses tend to be highly concentrated, and current federal programs already illustrate a strong public policy favoring subsidized medical care. ${ }^{128}$ Alternatively, of course, the statute could treat medical expenses like other special needs and simply exclude from available income any assistance given through current government programs. ${ }^{120}$

The double deduction for federal income taxes is an integral part of the special tax mechanism discussed in the annotation to section $7 .^{130}$ The limitation on this deduction is necessary to ensure that it does not become profitable for a family unit with a very high income to elect to be covered by the NIT as the tax obligation under the Internal Revenue Code approaches 50 per cent of the family unit's earned and imputed income.

The remaining deductions-support and alimony payments, gifts, and contributions to Social Security and pension plans-are necessary for consistent accounting.

The Internal Revenue Code of 1954 exempts certain corporations from the corporate income tax if the shareholders include undistributed taxable earnings of the corporation in their personal incomes. ${ }^{131}$ To prevent the use of such devices as percentage depletion in the computation of available income, family units must recompute income attributed to such corporations and include it within their available income under the same principles which would have applied had the business been unincorporated.

A similar problem occurs whenever a family unit receives income from a separately recognized entity such as a trust or corporation. Recomputation in these cases would normally impose too heavy a burden on the electing family unit, outweighing any possible improvement in the measurement of income. Such entities, unlike subchapter $S$ corporations, are subject to a

127. Cf. INT. REv. CODE of 1954, \& 165(c).

128. The medical deduction has frequently been favored even by proponents of a more comprehensive base for the positive tax. E.g., Musgrave, supra note 106, at 56. But sec Bittker, Response, supra note 106, at 1035. See generally R. GoOdE, supra note 104. Sec also HAving THE PowER, supra note 1, at 72.

129. This would avoid one of the anomalies in the statute as drafted. Payments under Medicare, Title 18 of the Social Security Act, 42 U.S.C. $\$ \$ 802,303,306$ (1965), are included within available income because they are made without regard to need. These payments will be netted out of available income only to the extent that they exceed the floor pro. vided in the statute. On the other hand, indirect payments or payments made under Medicaid, Title XIX of the Social Security Act, 42 U.S.C $\S 1396$ (1965), are not brought into available income at all. See Income Supplement Act \& 11(b)(17).

130. See also table, p. 271 supra.

131. INr. REV. CODE OF 1954, \$\& 1871-78. 
separate tax rate, and this may roughly compensate for any inequities which result from not looking behind their separate legal existence. ${ }^{132}$

\section{Section 12. Imputed Income Defined}

(a) General Rule.-For purposes of this Act, a person's imputed income for a supplement period of a full year shall be the sum of(I) an amount (not less than zero) equal to 5 per cent of the fair market value of the person's gross available capital, computed at the close of the supplement period, less the amount of any income derived from any interest included within gross available capital to the extent that:-

(A) such income is otherwise included within available income, and

(B) such income does not exceed 5 per cent of the value of the interest from which the income is derived, and

(2) the retail market value of food grown by a person or some member of his family unit and consumed by such person, minus the costs not otherwise deducted of producing such food.

For a supplement period of less than a year, a person's imputed income shall be computed as for a full year, except that the percentage of the fair market value of gross available capital and the percentage used in subsection (a)(1)(B) shall bear the same relation to 5 per cent as the supplement period bears to a full year.

(b) Gross Available Capital Defined.-For purposes of this Act, a person's gross available capital means gross capital, minus an exemption for the value of his clothing, furniture, automobiles, and other personal effects not used in a trade or business, not to exceed $\$ 1500$ for a claimant of $\$ 500$ for a dependent; provided, that the unused amount of a person's individual exemption may be used by any other member of the same family unit, but only to the extent that it has not been used by another person.

(c) Gross Capital Defined.-For purposes of this Act, a person's gross capital means all property, real or personal, tangible or intangible, wherever situated, to the extent of any of the person's interest therein, but excluding pensions and annuities. The value of an

132. For corporations the 48 per cent tax rate (computed on a slighty different base) means that retained income is taxed approximately the same as it would be if it were distributed to the shareholder. Distribution and the imposition of a second tax on dividends, however, means that the actual rate may be higher than that theoretically required. The problem of integrating the taxation of corporations and trusts are discussed 
interest in any property shall be reduced by the amount of any mortgage or indebtedness in respect to such property only to the extent that interest or other payments arising out of the mortgage or indebtedness have not been deducted in the computation of available income.

\section{Comment}

Section 12 is primarily an attempt to measure benefits which the family unit receives from personal assets. The most important example, of course, is the owner-occupied home. ${ }^{133}$ In order to equalize the positions of home owners and renters it is necessary to impute to the home owner the rental value of his home. Similar considerations require imputing a return to other property when the value of such property is sizable, whether or not it produces any income for purposes of ordinary taxation. Without such a provision, the ordinary taxpayer, using cash basis accounting, need not take into account any accrued gain until it is recognized by sale or exchange. Especially in the context of the NIT, the resulting postponement of gain would be inequitable since family units could receive net benefits in periods when they were enjoying significant but unrecognized gain.184

With regard to section 12 (and to section 13, which provides for the utilization of capital), it should be reemphasized that the "special tax" imposed by the statute is not a real tax, but only a mechanism to allocate income maintenance benefits according to need. ${ }^{135}$ The income imputed to a family unit by this section is included in available income, which is then "taxed" at the 50 per cent rate; but this treatment only attempts to insure that income maintenance benefits are distributed on a fair and equitable basis.

Under section 12, all assets have an imputed return of 5 per cent a year. This procedure avoids the difficulties of measuring actual accrued income, and serves, in addition, as a mild incentive for individuals to move their wealth out of relatively unproductive assets. The imputed return will also prevent such abuses as the hobby farm, in which losses are claimed for a nominal business actually operated for the owner's personal pleasure and recreation. On the other hand, this section could penalize such persons as

thoroughly in 4 Royal Commission on TAXation, Report 19.98 (1966) (Canacla). $b u l$ c). Bittker, Comprehensive Tax Base, supra note 106, at 977-80.

133. Such services have been a favorite target of those advocating reform of the posi. tive tax system. E.g., R. Goode, supra note 104, at 120-29; see also J. Pechinan, Fruerat. TAX Policy 79 (1966). For a brief discussion of various methods of imputing rent, sec $W$. Vickrey, AGENDA FOR Progressive TAXATION 18-24 (1947).

134. Bittker, Comprehensive Tax Base, supra note 106, at 958-61, 967-73.

135. See Income Supplement Act \& 7, Comment supra. Since the "special tax" is only a device for allocating benefits, there is no question of its being unconstitutional as a direct tax. 
the small businessman, who is dependent upon his own assets for employment and cannot easily shift to other investments. In part, then, this section cuts against the business loss deduction allowed by section 11 .

Imputed income is computed on a comprehensive base. Exempting only pensions and annuities, which are taxed on the basis of actual payments received, the base includes all real and personal property, without allowance for mortgages and indebtedness. This is necessary to compensate for the deduction of interest payments from available income. ${ }^{130}$ Of course, when an item is worth less than the debt it secures, the value on which income is imputed will be the lesser amount.

To simplify administration, subsection (c) provides an exemption for personal effects of $\$ 1500$ per claimant and $\$ 500$ per dependent. Therefore, the items most frequently included in gross available capital will be those of significant value, such as the family home and business or profit-producing assets. ${ }^{137}$

The section also requires a family unit to include the value of homegrown and home-consumed food in available income. This item may bulk large in the budgets of the rural poor, ${ }^{138}$ and its inclusion is necessary to give an accurate picture of rural incomes. Regulations under this section should establish rule-of-thumb estimates that can be applied in the absence of evidence to the contrary; such presumptions could, if desired, be written into the statute. ${ }^{139}$ The administrative difficulties in valuing other kinds of imputed income, such as home carpentry, dressmaking, and the liketogether with the typically smaller sums involved-make their inclusion not worthwhile.

\section{Section 13. Capital Utilization Income Defined}

(a) General Rule.-For the purposes of this Act, a person's capital utilization income for a supplement period of a full year shall be 30 per cent of the fair market value of his net available capital, com-

136. Since the cost of credit for individuals will normally be greater than 5 per cent, the 5 per cent imputed rate of return understates the actual expectations of investors and homeowners.

137. Of those families below the Social Security Administration's poverty line, 33 per cent possess some equity in their own homes, 12 per cent have some equity in business or professional assets, and only 5 per cent possess any equity in publicly traded stock or marketable securities. D. Projector \& G. WViss, Survey of Financial. Ciuaracteristics of Consumers, Table A4I, at 160-61 (1966). Because the special tax rate is 50 per cent rather than 100 per cent, families with incomes above these levels will, of course, also be filing for supplements. At least for the income group immediately above the Social Security index, however, the mean amount of equity in different holdings differs significantly only for investment assets. Id. Table A8 at 110 .

138. For the rural poor the average value of home grown food is estimated to be 10 per cent of their total income. Orshansky, I'ho's II'ho Among the Poor, supra note 87. at 9.

139. See, e.g., H.R. 17331, \& 1603(b), 90th Cong., 2d Sess. (1968). 
puted at the close of the supplement period. For a supplement period of less than a year, a person's capital utilization income shall be computed as for a full year, except that the percentage of fair market value of net available capital shall bear the same relntion to 30 per cent as the supplement period bears to a full year.

(b) Net Available Capital Defined.-For purposes of this Act, "net available capital" means gross available capital, as defined in section 12(b) minus-

(1) the amount of any mortgage or indebtedness in respect to property included within gross available capital,

(2) any other indebtedness not otherwise deducted,

(3) the difference between the current fair market value of the principal residence owned by the family unit and the maximum amount for which such property commerically could be mortgaged if it were otherwise unencumbered,

(4) an exemption of $\$ 5,000$ for a claimant or $\$ 3,000$ for a dependent, and

(5) an additional exemption for any property used in a trade or business not to exceed $\$ 5,000$ for a claimant.

The unused amount of a person's individual exemption under (4) and (5) above may be used by any other member of the same family unit, but only to the extent that it has not been used by another person.

\section{Comment}

Since the purpose of the income supplement is to assure every family a minimum level of consumption, the determination of a family's consumption resources must take account not only of its income but also of its wealth.140 How much of its wealth a family should use for current consumption of course varies with a number of factors, and any single rate will necessarily seem subjective and somewhat arbitrary. Adding wealth in toto to available income would discourage private savings and aggravate the social dislocations caused by sharp income declines. On the other hand,

140. Some families possess significant amounts of wealth, even though their incomes are below the poverty line. Eighteen per cent of such families in one survey reported wealth greater than $\$ 10,000$, six per cent had wealth of $\$ 25,000$ or morc. D. Projecron \& G. WEIss, supra note 137, at 37 . Since net worth is correlated with age, the general effect of including wealth would be to reduce the proportion of aged units among recipients. See generally Weisbrod \& Hansen, An Income-Net Worth Approach to Measuring Economic Welfare, 58 AM. EcoN. Rev. 1315 (1968) (economic welfare measured as the sum of current income and the annuity value of net worth). 
when income declines, this section requires families to supply at least part of their current needs out of savings. ${ }^{\text {I } 11}$ Finally, the inclusion of a portion of capital may protect against abuse of the program by persons with large property holdings and unrecognized gains, but low current incomes.

These considerations and the administrative need to ignore numerous small holdings suggest a combination of high initial exemptions and high rates of inclusion above the exemption level.142 Section 13 allow's each family a $\$ 5000$ exemption for claimants and a $\$ 3000$ exemption for dependents. Family exemptions may be aggregated for the family as a whole. Wealth above the family's exemption goes into available income at a 30 per cent rate, the equivalent of imposing a special tax of 15 per cent on the family's net worth above the minimum exemption. ${ }^{143}$

The base for determining capital utilization is net worth. Unlike the imputed income section, section 13 discounts indebtedness. To avoid any suggestion that the section would require home owners to sell their homes, subsection (b)(3) includes owner-occupied homes in the base only to the amount of a commercially obtainable mortgage.144 Subsection (b)(5) permits a small additional exemption for business or income-producing property to avoid requiring small businessmen to expend a portion of their business assets for current consumption needs. This problem could have been handled in the same way as owner-occupied homes, but business assetsepecially if they are movable-are not as easily or cheaply mortgaged as real estate.

An alternative approach to that of the statute would combine the imputed income and the capital utilization provisions into a single operation with a higher rate of inclusion. ${ }^{145}$ Functionally, the two sections both act to exclude persons with sizable assets, but analytically the two differ. The imputed income section attempts to measure income flows not otherwise included within the definition of available income, while the capital utilization section reflects an admittedly arbitrary assumption about how much of its accumulated capital a family unit should have to make available

141. See Tobin, Pechman \& Mieszkowski, supre note 6, at 16.

142. At the proposed levels, most low-income families, other than those with a retired head, would be relatively unaffected by this section. The mean amount of equity held by families below the Social Security poverty line in 1962 was $\$ 6032$, well below the $\$ 10,000$ exemption for a married couple. D. PROJEcTOR \& G. WeIss, supre note 137. Table A4I, at 162. The average for all families with $\$ 5000$ of income or less was $\$ 8610$. Derived from id. Table A8, at 110, \& Table A36, at 151. Even for units below the poverty level, however, the average wealth of families whose head was 65 or over was $\$ 12,611$. Id. A41, at 162 .

143. Including only part of wealth means that some families by drawing down their wealth will be able to maintain higher living standards than other families receiving the same NIT benefit. In particular, students or other who have temporarily withdrawn from the work force may be able to abuse the supplements by living off transfers or camings received in prior years while getting a subsidy. Even if wealth were fully included, some families could draw on future income by unsecured borrowing to maintain clevated standards of living while receiving supplements.

144. See Tobin, Pechman \& Mieszkowski, supra note 6 , at 18.

145. Id. 
for current consumption when its income is otherwise depressed. The analytic difference partially explains the different definitions of capital in the two sections: section 12 defines capital to include all of the resources currently at the command of the family-including actual borrowingwhile section 13 limits capital to net worth. Furthermore, since the imputed income section is designed to fill out the definition of available income, asset income included elsewhere is deducted from it. ${ }^{140}$ On the other hand, the capital utilization section is complete in itself and allows no deduction for items already included in available income. Of course, the two sections could still be combined by using a percentage inclusion factor for items now included in only one of the two bases, but a better understanding of the structure of the special tax base results from keeping them distinct.

Section 14. Basis

(a) General Rule.-Except as provided in subsection (b), the adjusted basis for determining the gain or loss from the sale or other disposition of property under this Act shall be the adjusted basis as defined by section 1011 of the Internal Revenue Code of 1954.

(b) Exceptions. - For the purposes of this Act the adjusted basis of any property (other than cash) used in a trade or business or held for the production of income shall be increased by-

(1) the amount of income imputed to the property under section 12 of this Act, and included within available income, less the amount of income includable within adjusted gross income as defined by section 62 of the Internal Revenue Code of 1954, and

(2) the amount of any deduction with respect to the property disallowed in computing available income to the extent that such deduction would result in a reduction of the adjusted basis of the property under section 1016 of the Internal Revenue Code of 1954 .

No adjustment may be made in respect to years in which the person holding the property did not belong to a family unit receiving income supplements in excess of its special tax liability under this Act.

\section{Comment}

Section 14(a) provides that, in general, the basis for property is the same under the proposed statute as it is under the Internal Revenue Code.

146. Notice that section $12(a)(1)(A)$ is limited to income actually derived from gross available capital and does not include capital utilization income. 
Because of the expanded definition of available income, however, compensating adjustments were necesary to avoid double taxation of certain items. ${ }^{147}$

\section{Section 15. Valuation}

(a) General Rule.-The Secretary of the Treasury or his delegate shall prescribe all necessary rules and regulations for the valuation of interests under this Act. When fair market value is not readily ascertainable, the Secretary or his delegate shall prescribe methods for approximating the value. Either the Secretary or the recipient may establish that actual value is greater or less than that ascertained by such methods, but the burden of proof shall rest on the party asserting the different value.

(b) Jointly Held Property.- Jointly held property, whether or not partitionable, shall for the purposes of this Act be treated as if orwed in separate proportional shares.

(c) Contingent and Conditional Interests.-Interests subject to a contingency or condition which may not otherwise be valued shall be valued as if the contingency or condition did not exist unless-

(1) the contingency or condition is real and substantial, and

(2) the contingency or condition does not depend upon a power exercisable by a person who is a member of the same family unit or who does not have an adverse interest, and

(3) the failure of the interest would not result in the interest passing beneficially to another member of the family unit-

in which case the interest shall be valued as zero. No interest,

147. Two important cases arise. The first, dealt with in section $14(\mathrm{~b})(2)$, results from disallowing deductions in computing available income of many items which the Intemal Revenue Code allows the taxpayer to deduct. For the purposes of the NIT these items should be capitalized and, if strict accrual principles of accounting were followed, recovered in subsequent years through larger depreciation deductions. To arry this approach through, however, would require separate computations of depreciation and de-
pletion for the NIT and the income tax even in jears in which the family unit was not receiving benefits from the NIT. The statute adopts the easier procedure of limiting deductions for depreciation and depletion to those permitted under the Internal Rerenue Code and compelling the taxpajer to wait until disposition of the asset to recover the capitalized expenditure.

A second adjustment, permitted by section $14(\mathrm{~b})(\mathrm{I})$, avoids the double inclusion of previously imputed income. Two features of this adjustment should be noted. First, adjustments may only be made to the basis of income producing or business property: i.e., the basis of an owner-occupied home could not be increased by the amount of income previously imputed to it. Secondly, adjustments are limited to items upon which the taxpayer has actually been subject to the special tax. Thus, a small businessman who sold his business would not be able to increase his basis by the amounts of income which would have been imputed to the business in previous years unless his family was in fact bencfitting under the NIT during those years. 
however, shall be attributed more than once to the same family unit.

\section{Comment}

The sweeping scope of both the imputed income and capital utilization sections requires in principle annual valuation of all capital assets. On its face this is an immense task which the Treasury is ill-equipped to meet, but in practice the burden may be considerably less. For many families total assets will not exceed the exemption levels so that precise valuation is unnecessary. ${ }^{148}$ Many will hold their assets in readily valued forms such as savings accounts or publicly held shares. The most troublesome cases will be small businesses, farms and owner-occupied homes. ${ }^{140}$

Since neither the individual family nor the government will be able to make precise valuations in these cases, the Treasury will have to construct general schedules. Section 13(a) specifically authorizes such an estimating process. Local real estate assessments, adjusted at several-year intervals by more individualized surveys, could also serve for much of the valuations with rough estimates used for adjustments in intermediate years. ${ }^{100}$ To a large extent, however, the Treasury will have to depend on the claimant's valuation, recognizing that in the absence of actual sales or realizations, values will normally be understated.

Special provisions are made for valuing certain types of interests. 151 When valuations are disputed by either the taxpayer or the Secretary, the statute provides for administrative appeal and judicial review.152

\section{Section 16. Methods of Accounting}

(a) Method of Accounting.-Available income shall be computed under the method of accounting regularly used by the claimants of the family unit in computing income tax liability. Where two

148. See note 143 supra.

149. For the distribution of wealth held by poverty units, see D. Projector \& G. WEIss, supra note 137, Table A41, at 162.

150. Cf. E. Edwards \& P. Bell, The Theory and Measurement of Business Income $185-88$ (1961); Bittker, Comprehensive Tax Base, supra note 106, at 968.69. See also $M$. David, Alternative Approaches to Captral Gains Taxation 214-15 (1968).

151. Under section 15 (b) joint interests are treated as severable regardless of local law and are valued accordingly. Section $15(c)$ deals with conditional interests arising primarily with respect to trusts. Probably less than one per cent of the eligible families have assets of this nature, but for those who do many difficult problems may arise. Valuation in somo cases may be made on the basis of mortality tables or other statistics, but in others no precise value may be assigned. With the income and gift taxes the problem may be solved by leaving valuation open, but for the purposes of this Act some annual value must be established. Except for the most substantial limitations, section 15 (c) disregards the contingency. Obviously, experience may suggest further refinements in such a blanket rule.

152. Income Supplement Act \& 19(c) to $-(f)$. 
claimants in a family unit use different methods in computing income tax liability, the family unit shall use the method followed by the claimant whose taxable year serves as the basis of the family unit's supplement period, under section $4(a)$ of this Act. If no method of accounting has been regularly used by such claimants, or if the method used does not clearly reflect income, the computation of available income shall be made under the cash receipts and disbursements method or such other method that does clearly reflect income.

(b) Special Rule.-Where an item of income or deduction may not be properly attributed to a specific period of time, such item of income or deduction shall be deemed to accrue ratably during the calendar year.

(c) Apportionment Among Individuals. - The Secretary or his delegate may apportion items of income, deductions, or credits, among individuals if such apportionment is necessary in order to prevent evasion of taxes or to reflect clearly the income of such individuals for purposes of subsection (a).

\section{Comment}

The rules set out in section 16 for methods of accounting correspond closely to those established for positive income tax purposes. 163 The vast majority of electing family units will undoubtedly use the cash receipts and disbursements method, but the statute leaves room for the use of various accrual methods.

In the case of family units containing one or more persons filing income tax returns, the choice of accounting method must be the same for NIT and income tax computations. The compatibility of records which this requirement achieves should be of substantial aid in verifying both sets of returns.

Section 17. Glaims Against Supplement Payments Prohibited

(a) Assignment and Taxation.-Payments of benefits due or to become due under this Act shall not be assignable and shall not be subject to taxation under the Internal Revenue Code of 1954 or to any other taxation.

(b) Other Claims.-Payments of benefits due or to become due under this Act shall be exempt from the claims of creditors and from any

153. See INT. REv. CODE OF 1954, \$ 446. 
process of attachment or levy, or from seizure by or under any legal or equitable process whatsoever before receipt by the beneficiary; provided, that this subsection shall not apply to claims of the United States, which accrue under the provisions of this Act or, subject to the prohibition in subsection (a), under the provisions of the Internal Revenue Code of 1954.

\section{Comment}

The safeguards provided by section 17 reinforce the guarantee of a minimum standard of living which lies at the heart of the NIT. Both the income guarantee and the work incentive aspects of the plan would be jeopardized were the supplement subject to whole or partial confiscation before receipt. The protection offered by this section is similar to that which now applies to public assistance payments and veterans' benefits. ${ }^{154}$

Certain claims of the United States are exempted primarily to enable recovery of excessive semimonthly payments under section 8 , although the exemption extends to amounts owed the federal government under positive income tax laws. Any deduction from advance payments on account of such liability, however, is limited by subsection $8(j)$.

\section{Section 18. Records and Returns}

Every claimant in an electing family unit shall keep such records, render such statements, and make such returns as are required by this Act and the regulations thereunder. Every claimant required to make a return or statement shall include therein the information requested by such forms and regulations as may apply, provided that such requests are reasonable and necessary and do not violate the recipient's right to privacy. All rules and regulations requiring the disclosure of information shall be subject to the review provisions of section 19 of this Act.

\section{Section 19. Procedural Rights and Review}

(a) Rules and Regulations. - The Secretary shall make all rules and regulations under this Act on the record and after an opportunity for a hearing in the manner prescribed by Chapter II of Title 5 of the United States Code, except as expressly modified herein.

154. E.g., 42 U.S.C. $\$ 406$ (1964) (Federal Old-Age, Survivors, and Disability Insurance
enefits). Benefits). 
All such rules and regulations shall be reviewable in a federal court of competent jurisdiction.

(b) Recipients' Organizations.-The Secretary or his delegate shall maintain a list of all organizations which certify that they have a membership of more than fifty people receiving benefits under this act and shall send to such organizations all proposed rules and regulations at the time that they are published in the Federal Register. These organizations shall have standing to participate in any public hearing held to review a rule or regulation, and to challenge any proposed rule issued under this Act in a federal court.

(c) Information.-The Bureau of Income Maintenance shall from time to time extensively publicize the benefits available under this Act, using all appropriate media of communication. The Bureau shall diligently and fully inform all applicants, in simple and understandable writing, of their rights under the Act and especially of their rights to benefits, to a hearing and appeal, to judicial review, and to payment of costs as provided in this section.

(d) Due Process Hearing.- Upon request in writing, the Secretary or his delegate shall afford opportunity for a full due process hearing before an examiner with respect to any action of the Secretary or his delegate denying, withholding, or modifying a family unit's income supplement, including semimonthly payments, or any part or portion thereof, to any person aggrieved by such action. Such hearing if requested shall occur prior to the effective date of any such denial, withholding, or modification, unless all individuals aggrieved by the action request in writing that it occur after such effective date. All aggrieved individuals shall be entitled to representation by counsel at such hearings, to present evidence in their own behalf, to know the evidence against them, to confront and cross-examine witnesses against them, and to challenge the reasonableness of any rule, regulation, or practice adopted pursuant to this Act as applied to their case. At the conclusion of a hearing held pursuant to this subsection, the trial examiner shall make findings of fact and shall issue a written decision based upon the evidence adduced at such hearing and stating the reasons for his decision. All hearings provided for under this subsection shall be open to the public unless any one of the aggrieved individuals request in writing that the hearing be closed. The Secretary and the aggrieved parties shall be bound by the decision of the trial examiner unless an appeal is taken to the Board of Appeals within 
30 days of that decision. Such appeal shall be heard and decided before the action sought by the Secretary shall be effective.

(e) Right of Administrative Appeal.-The Secretary shall establish a Board of Appeals which shall review the findings, rulings, and decisions of the trial examiner in the hearings provided for in subsection (d) upon the request of any party thereto. The Board shall publish its decisions and state the reasons therefor. The Secretary and the aggrieved parties shall be bound by the decision of the Board unless judicial review is sought pursuant to subsection ( $f$ ). The Board's decision shall take effect when rendered, unless stayed by an appropriate court pursuant to subsection (f).

(f) Judicial Review.-Decisions of the Secretary or his delegate denying, withholding, modifying, or affecting an individual's income supplement, including semimonthly payments, shall be fully reviewable by a civil action commenced in the United States district court for the district in which the recipient resides. The district courts shall have jurisdiction of such actions without regard to the amount in controversy.

(g) Paid Expenses. - All persons shall be entitled to reasonable expenses incurred in any hearing or judicial review brought under this section, including necessary child-care, loss of pay, transportation expenses for the aggrieved parties and their witnesses and representatives, reasonable expenses necessary for the adequate preparation of the case, reasonable attorneys' fees, and any other expenses reasonably and necessarily related to the hearing or case; provided, that a district court, in a proceeding before it under this Act, may disallow expenses related to court proceedings if it finds that a party or his attorney has acted frivolously or in bad faith.

(h) Complaint Review Board.-The Secretary shall establish a Complaint Review Board to review any complaint that a Bureau em. ployee is not performing his functions properly or is not following properly issued regulations. The Board shall, after notice to the employee, promptly investigate the complaint and send the results of its findings with respect to any complaint in writing to the person or organization making the complaint, and to the employee, within 60 days of the receipt of such complaint. In the event that the Board finds the employee guilty of willful or grossly negligent disregard of the rights of any person under this Act and the regulations issued pursuant to it, or of a serious and willful or grossly negligent abuse of discretion, or of willful or grossly negligent failure to perform his functions properly, the Secretary or his 
delegate shall conduct a hearing on the charge in which the employee and the complainant shall have standing to participate. If the results of the hearing sustain the findings of the Board, the Secretary shall take such disciplinary action, not excluding discharge or suspension without pay, as he deems proper and as authorized by the Civil Service laws of the United States.

(i) Confidentiality.-All records kept by the Bureau of Income Maintenance shall remain strictly confidential and may be used only by the Bureau and the Internal Revenue Service to effectuate and enforce the provisions of this Act, except that a claimant shall at any time be entitled to examine his own file at the local office of the Bureau by submitting a written request.

(j) Investigations. - The Secretary or his delegate may not conduct investigations with respect to more than 5 per cent, randomly selected, of all family units electing to receive benefits under this Act in any calendar year, except that the Secretary or his delegate may investigate whenever probable cause exists to believe that a family unit is not entitled to receive the benefit for which it applied or which it has received, and except that the preceding limitations shall not apply to routine investigations undertaken in connection with hearings held under subsection (d).

\section{Comment}

Section 19 attempts to set in concrete terms the guiding principle of the NIT: benefits are a matter of right, not grace. Turning the abstract right into practical reality requires specific safeguards from the beginning of the process to the end. ${ }^{155}$ As the Supreme Court has recognized in the case of constitutional rights, people cannot make effective use of their rights without knowledge of their existence. 168

One major obstacle to reform of the present welfare apparatus has been the diffculty in challenging arbitrary or unreasonable rules either administratively or judicially. ${ }^{167}$ Welfare departments often refuse to provide internal review procedures of their rules, ${ }^{188}$ and if review is provided, it is

155. This section draws heavily from An Analysis of the New Rules Goveming Welfare Hearings Proposed by the [New York] State Board of Social Welfare and the Subjeet of Public Hearings, July 21, 1961 (Center on Social TWelfare Policy and Law 1967). reprinted in Materials on Public Assistance. (E. Sparer \& B. Glick eds. 1967) (mimeographed copy on file at the Yale Law School Library). See also HAving THE PowER, supra note 1, at 67-74. 156. See, e.g., Miranda v. Arizona, 384 U.S. 436 (1966); Income Maintenance Hearings $54-55$.

157. Handler, Controlling Official Behavior in Welfare Practices, 54 CALIF. L. REv. 479. 481 (1966); Reich, The New Property, 73 Yale L.J. 733, 783 (1964).

158. Note, Federal Judicial Review of State Welfare Practices, o7 Colus. L. REv. 84, 92 n.56 (1967). 
quite inadequate. ${ }^{159}$ Section 20 (a) brings NIT rule-making within the provisions of Title 5 of the U.S. Code ${ }^{160}$ (formerly the Administrative Procedure Act) for advance promulgation of the rules, ${ }^{161}$ opportunity to participate in a public hearing, ${ }^{162}$ and finally opportunity to attack the rule directly in court. ${ }^{163}$ Since most affected parties are likely to be poor and therefore unable to participate effectively in such procedures as individuals, the section requires as a further safeguard that the government notify recipients' organizations of all new rules and allow them to participate in the hearing and challenge the rules in court.

Section 19 also requires a full due process hearing before the Secretary or his delegate can withhold any portion of a supplement payment. A hearing prior to final action is necessary for two reasons. First, income supplements may represent the only source of money income available to a family: it is certainly unfair to starve a family for several months while the government debates its eligibility. ${ }^{164}$ Second, paying out benefits puts pressure for prompt adjudication on the government, while deferring payments until after the hearing rewards slow and inefficient review techniques. Reducing a family unit's benefit or cutting it off completely without the opportunity for a prior hearing also raises serious constitutional problems. ${ }^{105}$

Full due process implies a right of confrontation, cross-examination, ${ }^{100}$ and assistance of counsel ${ }^{167}$ on any ruling adverse to a person's interests under the program. The burden of requesting a hearing rests on the recipient, but the government has the clear burden of apprising him of his right to do so. Subsection (e) establishes one appeal as of right within the internal administrative structure. The fairness and impartiality of this machinery should, of course, be subject to judicial scrutiny, and subsection (f) explicitly guarantees recipients broad review in a federal district court, regardless of the amount in controversy.

The rights to hearing, appeal, and judicial review would be empty prom.

159. Id. 92.94.

160. 5 U.S.C. $\$ 500$ (Supp. II, 1967). Section 21(c) amends title 5 to take the NIT out of the "public benefits" exception contained in 5 U.S.C. $\$ 553(\mathrm{a})(2)$ (Supp. II, 1967).

161. 5 U.S.C. \$ 553(b) (Supp. II, 1967).

162. 5 U.S.C. §§ 553(e), 556, 577 (Supp. II, 1967).

163. 5 U.S.C. \$ 702 (Supp. II, 1967).

164. See Note, supra note 158 , at $92-94$.

165. Note, Withdrawal of Public Welfare: The Right to a Prior Hearing, 76 Yate L.J. 1234 (1967). See Kelly v. Wyman, 37 U.S.L.W. 2324 (S.D.N.Y. Nov. 26, 1968) (three-fudge court) ("The stakes are simply too high for the welfare recipient, and the possibility for honest error or irritable misjudgment too great, to allow termination of aid without giving the recipient a chance, if he so desires, to be fully informed of the case against him so that he may contest its basis and produce evidence in rebuttal.")

166. See Willner v. Committee on Character and Fitness, 373 U.S. 96, 103.01 (1963); Garrott v. U.S., 340 F.2d 615 (Ct. Cl. 1965). Professor Reich has cogently suggested that the full battery of formal adjudicatory procedures are more important in welfare cases than in business regulation, where they currently exist. Reich, Individual Rights and Social Welfare:The Emerging Legal Issues, 74 YALE L.J. 1245, 1253 (1965).

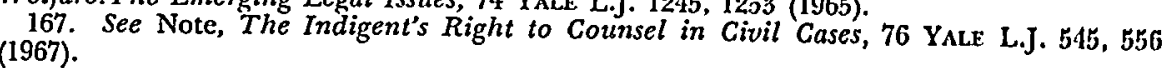


ises, however, if the government did not pay the reasonable expenses of exercising them. ${ }^{168}$ Offering a poor man the opportunity to vindicate his rights is of little value if it costs more money than he has. ${ }^{109}$ Moreover, the government should be realistic in estimating what expenses are involved: mothers must hire baby-sitters, working men must take time off, lawyers must be paid, and money must be provided for preparation of the case. ${ }^{178}$ To discourage frivolous appeals, the district court has power to deny all or part of court-related expenses.

Subsection (i) expressly makes all the information obtained by the Bureau of Income Maintenance confidential. It also, however, prohibits the long-standing welfare practice of denying the recipient access to his own file.171 Confidentiality is for the protection of recipients and ought not to be used to hinder them in obtaining their due. In addition, the right to inspect one's own file is probably implicit in the statute's earlier requirement of a due process hearing. ${ }^{172}$

Section 19 also establishes a complaint review board to review allegations of official misconduct. ${ }^{173}$ Since many people will depend on NIT payments for their basic subsistence, specific avenues of recourse must be provided to ensure that they do not suffer improper and illegal conduct in silence. To deter recurring official misconduct, to preserve the recipient's sense of dignity, and to equalize the power of recipients and bureaucrats, the recipient has the power to initiate an investigation into alleged misconduct and to present his case formally.

Finally, under subsection (j) the NIT is placed on an affidavit or declaration system, basically similar to the operation of the positive tax. The recipient is taken at his word with only small-scale, random investigations serving to deter fraud. Recent experiments and studies have demonstrated that the poor, as a group, are as honest as the rest of the population, ${ }^{174}$ and they should not be saddled with particular distrust simply because they are poor. ${ }^{175}$

Section 20. Application of Income Supplement Laws

(a) Powers and Duties of Secretary.-Except as otherwise expressly provided by law, the administration and enforcement of this Act

168. See Note, supra note 158 , at 93 .

168. See Note, supra note 158, at 93. .S. 353 (1963); Grifin v. Illinois. 351 U.S. 12 (1950).

170. The Criminal Justice Act, 18 U.S.C. $\$ 3006 \mathrm{~A}$ (d) to -(c) (1964), could provide a tentative model on which to build.

171. See Mraterials, supra note 155, at VIII-55 to VIII-58.

172. Cf. Jencks v. United States, 353 U.S. 647 (1957).

173. Cf. Income Mraintenance Hearings 61 (demand for procedures for airing grictances).

174. See id. 11, 17, 529.

175. See Income Maintenance Hearings 97-98. 
shall be performed by or under the supervision of the Secretary of the Treasury.

(b) Bureau of Income Maintenance.-There shall be established in the Department of the Treasury a Bureau of Income Maintenance. The Commissioner of Income Maintenance shall be the chief officer of the Bureau, shall be appointed by the President, by and with the advice and consent of the Senate, and shall serve at the pleasure of the President. The Commissioner of Income Maintenance shall have such duties and powers as may be prescribed by the Secretary.

(c) Appointment.-The Secretary or his delegate is authorized to appoint or employ in the Bureau of Income Maintenance such persons as the Secretary or his delegate deem proper for the administration and enforcement of the income maintenance laws. The Secretary or his delegate shall issue all necessary directions and rules applicable to such persons.

(d) Regulations.-The Secretary or his delegate shall prescribe all rules and regulations necessary for the enforcement and administration of this Act; provided, that such rules and regulations shall accord with the purposes and policies of this Act as set out specifically in section 1 and as embodied in other sections of this Act.

(e) Service.-The Bureau of Income Maintenance shall also establish and maintain local counselling offices for the convenience of claim. ants and shall render assistance to claimants in the preparation of returns and other materials required by law.

\section{Comment}

If the NIT is to represent a complete break with the present methods and traditions of welfare, the bureaucracy which has grown up around public assistance should not be the one to administer the new program. Nor is there a place for income maintenance in a highly political department, where fluctuations in public opinion could seriously affect its funding. The NIT needs an organization which can serve the poor without stigmatizing them, and neither state welfare agencies nor the Department of Health, Education and Welfare meets this requirement.

The logical first choice for executing the statute seems to be the Internal Revenue Service. The IRS enjoys an unusual degree of political independence, operates for the most part impartially, and already has the facilities to deal with large numbers of returns, collections, and disbursements. Moreover, the Service has had extensive experience with broad base taxation.

Despite its advantages, however, the IRS has a natural bias toward col. 
lecting money rather than distributing it, and this could result in an admin. istration incompatible with the objectives of NIT.170 Section 20, therefore, resolves the problem of where to locate the program by creating an entirely new agency, the Bureau of Income Maintenance.

The Bureau of Income Maintenance will operate within the Department of the Treasury, thereby retaining most of the administrative advantages possessed by the IRS. In fact, the new agency will have a role similar to that filled by the Internal Revenue Service in enforcing the tax laws, and the functions delegated to the Commissioner of Income Maintenance should closely resemble those which the Commissioner of Internal Revenue now performs.

To ensure that the NIT works effectively, the Bureau will have to assume the burden of publicizing the program, as provided in section 19, and of carefully informing its clients of their rights and obligations under the Act. At the very least, the Bureau must establish local offices in areas readily accessible to those most likely to participate and must inform applicants in clear and simple language what they are entitled to and how they can obtain it. Again like the IRS, local Bureau officials should assist claimants in filing elections, preparing returns, and calculating the amount of their net benefits.

\section{Section 21. Amendments}

(a) Exemption of Income Supplements.-Section 123 of the Internal Revenue Code of 1954 is amended by adding at the end of subsection (a) the following subsection:

"(19) Benefits under the laws administered by the Bureau of Income Maintenance, see $\S 17$ of the Income Supplement Act of 1969."

(b) Income Averaging.-Section 1303 of the Internal Revenue Code of 1954 is amended by adding the following subsection:

“(e) Individuals Receiving Income Supplements. An individual shall not be eligible for the computation year if at any time during the year or the base period he was a claimant under the Income Supplement Act of 1969."

(c) Rule Making Requirements to Apply.-Section 553(a)(2) of Title 5 of the United States Code is amended to read as follows:

"(2) a matter relating to agency management or personnel or to public property, loans, grants, benefits (but not including benefits under the Income Supplement Act of 1969), or contracts."

176. See C. GREEN, supra note 5, at 111-12. 